\title{
GENERATIONAL ACCOUNTS: A MEANINGFUL ALTERNATIVE TO DEFICIT
ACCOUNTING
}

Alan J. Auerbach

University of Pennsylvania and NBER

Jagadeesh Gokhale

The Federal Reserve Bank of Cleveland

Laurence I. Kotlikoff

Boston University and NBER

\section{EXECUTIVE SUMMARY}

This paper presents a set of generational accounts that can be used to assess the fiscal burden current generations are placing on future generations. The generational accounts indicate, in present value, the net amount that current and future generations are projected to pay to the government now and in the future. These accounts can be understood in terms of the government's intertemporal (long-run) budget constraint.

We thank Jinyong Cai, Ritu Nayyar, and Bash Hardeo for excellent research assistance and Albert Ando, David Bradford, Bill Gavin, and Mark Sniderman for very helpful comments. We are particularly grateful to Jane Gravelle for providing a variety of critical data and for numerous lengthy and extremely useful discussions. We thank The National Institute of Aging and The National Bureau of Economic Research for research support. 
This constraint requires that the sum of generational accounts of all current and future generations plus existing government net wealth be sufficient to finance the present value of current and future government consumption.

The generational accounting system represents an alternative to using the federal budget deficit to gauge intergenerational policy. From a theoretical perspective, the measured deficit need bear no relationship to the underlying intergenerational stance of fiscal policy. Indeed, from a theoretical perspective the measured deficit simply reflects economically arbitrary labeling of government receipts and payments.

Within the range of reasonable growth and interest rate assumptions the difference between age zero and future generations in generational accounts ranges from 17 to $24 \%$. This means that if the fiscal burden on current generations is not increased relative to that projected from current policy (ignoring the just enacted federal budget deal) and if future generations are treated equally (except for an adjustment for growth) the fiscal burden facing all future generations over their lifetimes will be 17 to $24 \%$ larger than that facing newborns in 1989. The just enacted budget will, if it sticks, significantly reduce the fiscal burden on future generations.

The calculations of generational accounts reported here are based solely on NIPA government receipts and expenditures, and reflect the age pattern of government receipts and payments as well as the projected substantial aging of the U.S. population.

\section{INTRODUCTION}

The federal deficit is widely viewed as the United States' number one economic problem. Yet there is no consensus as to how to measure the deficit. Some want to exclude the current social security surplus, others want to include the full value of the S\&L bail out, and others are concerned about adjustments for unfunded government retirement liabilities, inflation, growth, and government acquisition and sale of assets. The debate has not been restricted to politicians. Economists have played a major role in lobbying for their favorite definitions of the deficit (e.g., Feldstein, 1974; Eisner and Pieper, 1984).

Of course, a lot is at stake in how one measures the deficit. Given current policy, leaving out social security surpluses means whopping deficits through the 1990s, while adjusting for inflation and growth almost turns the officially defined deficit into a surplus. As the underlying credo of fiscal policy is to cut spending or raise taxes to make the deficit zero, the attention given to how to define the deficit is not surprising.

The goal of setting the deficit to zero seems quite strange in light of our 
uncertainty about how the deficit should be measured. If we are not sure what the deficit is, how can we be sure it should be zero? Rather than continue debating the deficit's measurement, perhaps we should first ask what concept the deficit is supposed to measure and then determine a measure consistent with that concept.

The conceptual issue associated with the word "deficit" is the intergenerational distribution of welfare. Specifically, how much are different generations paying to finance government consumption and to subsidize each other? Unfortunately, from the perspective of economic theory, the deficit is an arbitrary accounting construct whose value has no necessary relation to the question of generational burdens. As demonstrated by Kotlikoff $(1984,1988,1989)$ and Auerbach and Kotlikoff (1987), from a theoretical perspective the government can run any fiscal policy it chooses while simultaneously reporting any size deficit or surplus. It can do so simply through the choice of how it labels its receipts and payments. For example, the government can (and does) label workers' social security contributions "taxes" and retirees' social security benefits "transfers." Suppose, instead, the government labeled workers' contributions "Ioans" to the government and retirees" benefits "return of principal and interest" on these "loans" plus an additional "old age tax" equal to the difference between benefits and the "return of principal plus interest" on the "loans." In this case the reported deficit would be entirely different not only with respect to its level, but also with respect to its changes over time. ${ }^{1}$ This is not an isolated example; every dollar the government takes in or pays out is labeled in. a manner that is economically arbitrary.

If the deficit has no intrinsic relation to generational policy, what measure does? The answer according to economic theory is what we term generational accounts. These are accounts-one for each generation-that tally up, in present value, the amount of receipts less payments the government can expect to collect from each generation over its remaining life span. These generational accounts are comprehensive in that they consider all receipts and payments collected from or paid to all federal, state, and local govermments. In contrast to the deficit, generational accounts are invariant to changes in accounting labels. This may be seen, for example, by considering the alternative labeling of social security just discussed. For each generation the present value of its social security "tax" contributions less its receipts of "transfers"

\footnotetext{
1. The Economic Report of the President 1982-Appendix to Chapter 4 reports both the conventional deficit and the deficit that arises from defining social security contributions as "loans" to the government.
} 
consisting of social security benefits is identically equal to the present value of its "old age tax."

The generational accounts are discussed in the context of the government's intertemporal budget constraint, which states that the government's current net wealth plus the present value of the government's net receipts from all current and future generations (the generational accounts) must be sufficient to pay for the present value of the government's current and future consumption. By comparing what the government is projected to take from current generations with the difference between its projected consumption expenditures and its current net wealth, one can estimate the amount that future generations will need to pay. Hence, the generational account approach indicates directly the burden on future generations imposed by increases in expenditures on existing generations, including existing elderly generations. This "zero sum" feature of the government's intertemporal budget constraint (some generation has to pay for any benefit to another generation) imposes a useful discipline on fiscal analysis. If the government were to adopt the accounting framework developed in this study, it would be required to specify the costs to be borne by future generations for programs that help existing generations, and vice versa.

The generational accounts can also be used to assess the effects on national saving of programs to redistribute more or less to current generations. For example, a decision to lower Medicare benefits means an increase in the expected present value of net payments to the government by the existing elderly. The change in the present value accounts of each elderly generation due to this policy represents the change in their lifetime resources. Using recent generation-specific estimates of the propensity to consume out of lifetime resources developed by Abel, Bernheim, and Kotlikoff (1991), one can consider the effect on national consumption and national saving of such policy changes.

The primary sources of data used in this study are the Bureau of the Census' Survey of Income and Program Participation (SIPP), the Social Security Administration's population projections, the Bureau of Labor Statistics Consumer Expenditure Surveys (from 1980 onward), and the National Income and Products Accounts reported in the July 1990 Survey of Current Business.

The findings of this paper suggest a larger fiscal burden-17 to $24 \%$ Iarger--on future generations than the burden to be imposed on 1989 newborns under current policy (ignoring the recently enacted federal budget deal). These figures are adjusted for growth, i.e., the increase is 17 to $24 \%$ above the increase in fiscal burden that would accompany trend growth. The assessment that future generations face 17 to $24 \%$ higher 
net taxes over the course of their lifetimes suggests a significant generational problem. The recently enacted federal budget deal will, if it is not subverted, substantially reduce, if not eliminate the additional burden that would otherwise be imposed on future generations.

The paper continues in Section II with a more precise description both of generational accounts and their relationship to the government's intertemporal budget constraint. Section III describes how one can use the generational accounts to assess the generational stance of fiscal policy. Section IV considers the relationship of each generation's account to its own lifetime budget constraint. Section $\mathrm{V}$ provides a detailed description of the data sources and methodology used in calculating the generational accounts. Section VI presents our findings, including our policy simulations. Our findings should be viewed as preliminary because there are a number of aspects of our calculations that can be improved with the additional data that we are in the process of procuring. We simulate (1) the President's proposed capital gains tax cut, (2) eliminating the 1983 social security benefit cuts scheduled to go into effect around the turn of this century, (3) growth in Medicare spending in excess of the economy-wide growth rate, (4) the impact of the $\$ 500$ billion S\&L bailout, (5) slower growth in government consumption spending, and (6) the budget deal just enacted by Congress and signed by the President. Finally, Section VII summarizes our findings and draws conclusions.

\section{GENERATIONAL ACCOUNTS}

The term "generations" refers in this paper to males and females by specific years of age. The term "net payments" refers to the difference between government tax receipts of all types (such as federal and state income taxes) and government transfer payments of all types (such as social security benefits, unemployment benefits, and food stamps). Finally, all present values reflect discounting at a pretax interest rate.

To make the generational accounts and their relationship to the government's budget constraint more precise, we write the government's intertemporal budget constraint for year $t$ in equation (1):

$$
\sum_{s=0}^{D} N_{t, t-s}+\sum_{s=1}^{*} N_{t, t+s}+W_{i}^{g}=\sum_{s=t}^{s} G_{s} \prod_{j=1}^{s} \frac{1}{\left(1+r_{j}\right)}
$$

The first term on the left hand side of (1) adds together the present value of the net payments of existing generations. The expression $N_{t, k}$ stands 
for the present value of net remaining lifetime payments to the government of the generation born in year $k$ discounted to year $t$. The index $s$ in this summation runs from age 0 to age $D$, the maximum length of life. Hence, the first element of this summation is $N_{t, t}$, which is the present value of net payments of the generation born in year $t$; the last term is $N_{t, i-0}$ the present value of remaining net payments of the oldest generation alive in year $t$, namely those born in year $t-D$. The second term on the left hand side of (1) adds together the present value of remaining net payments of future generations. The third term on the left-hand side, $W_{i}$, denotes the government's net wealth in year $t$. The right-hand side of (1) expresses the present value of government consumption. In the latter expression, $G_{s}$ stands for government consumption expenditure in year $s$, and $r_{j}$ stands for the pretax rate of return in year $j$.

Equation ( 1 ) indicates the zero sum nature of intergenerational fiscal policy. Holding the right-hand side of equation (1) fixed, increased (decreased) government payments to (receipts taken from) existing generations means a decrease in the first term on the left-hand side of (1) and requires an offsetting increase in the second term on the left-hand side of (1), i.e., it requires reduced payments to or increased payments from future generations.

The term $N_{t, k}$ is defined in equation (2):

$$
N_{t, k}=\sum_{s=\max (t, k]}^{k+D} \bar{T}_{s, k} p_{s, k} \prod_{j=i+1}^{s} \frac{1}{1+r_{j}}
$$

In expression (2) $\bar{T}_{s, k}$ stands for the projected average net payment to the government made in year $s$ by a member of the generation born in year $k$. By a generation's average net payment in year $s$ we mean the average across all members of the generation alive in year $s$ of payments made, such as income and FICA taxes, less all transfers received, such as social security, AFDC, and unemployment insurance. The term $P_{s, k}$ stands for the number of surviving members of the cohort in year $s$ who were born in year $k$. For generations who are born prior to year $t$, the summation begins in year $t$. For generations who are born in year $k$, where $k>t$, the summation begins in year $k$. Regardless of the generation's year of birth, the discounting is always back to year $t$.

A set of generational accounts is simply a set of values of $N_{t, k t}$ one for each existing and future generation, with the property that the combined total value adds up to the right-hand side of equation (1). In our calculation of the $N_{t, k}$ s for existing generations (those whose $k \leq 1989$ ) we 
distinguish male from female cohorts, but, to ease notation, we do not append sex subscripts to the terms in (1) and (2).

\section{ASSESSING THE INTERGENERATIONAL STANCE OF FISCAL POLICY}

Once we have calculated the right-hand side of equation (1) and the first term on the left-hand side of equation (1), we determine, as a residual, the value of the second term on the right-hand side of equation (1), which is the present value of payments required of future generations. We further determine the amount that needs to be taken from each successive generation to balance the government's intertemporal budget, assuming that each successive generation's payment is the same up to an adjustment for real productivity growth.

This growth-adjusted constant amount is what must be taken from successive generations to maintain what Kotlikoff (1989) terms "fiscal balance"; one can compare this measure with the actual amount projected to be taken under current policy from existing generations, particularly the generation that has just been born. In other words, these data provide the answer to the question: Given the projected treatment of current generations as reflected in the values of their $N_{t, k} 5$, do we need to take substantially more from future generations than we are planning (as reflected by current policy) to take from current generations? In particular is $N_{t, t}$ substantially smaller than $N_{t, t+1}$ under the assumption that all values of $N_{t, s}$ for $s>t+1$ equal $N_{t, t+2}$ except for an adjustment for productivity growth? ${ }^{2}$

Note that our assumption that all values of $N_{i, s}$ for $s>t+1$ are equal, except for a growth adjustment, is just one of many assumptions one could make about the distribution across future generations of their collective net payment to the government. We could, for example, assume a phase-in of the additional fiscal burden (which could be negative) to be imposed on new young generations. Clearly, such a phase-in would mean that new young generations born after the phase-in period has elapsed would face a larger (possibly smailer) $N_{t, s}$ than we are caiculating here. Our purpose in assuming (1) growth-adjusted equal treatment of future generations and (2) that the $N_{t, s} s$ of current generations are those one would project under current policy is to illustrate the potential intergenerational imbalance in fiscal policy and the potential

${ }^{2}$ Our question is related to that posed in recent empirical studjes (e.g. Hamilton and Flavin, 1986, and Wilcox, 1989), which asks whether government debt will explade given current policy. However, we address the question of intertemporal government budget balance in a different, and, in our view, more satisfactory manner. 
need for adjusting current fiscal policy. It is not to claim that policy will necessarily deal with the intergenerational imbalance by treating all future generations equally or, indeed, by putting all the burden on future generations.

Understanding the size of the $N_{t, k}$ for current generations and their likely magnitude for future generations is not the end of the story with respect to assessing the intergenerational stance or incidence of fiscal policy. As studied in Auerbach and Kotlikoff (1987), intergenerational redistribution will alter the time path of factor prices and, thereby, the intergenerational distribution of welfare. Such changes in factor prices result from changes in the supply of capital relative to labor. But the changes in the supplies of capital and labor can, in turn, be traced back to changes in consumption and labor supply decisions, which are based on private lifetime budget constraints. As described in the next section, the $N_{1, s}$ s enter private budget constraints. Hence, knowing how their values change is essential not only for understanding the direct effect of government policy on the intergenerational welfare distribution, but also for assessing the changes in factor prices that may result from the policy. In short, then, understanding fully the incidence of intergenerational fiscal policy requires knowledge of changes in the values of the $N_{t, k} s$ arising from the policy.

Indeed, one of the future goals of this research is to consider how policies other than those examined here might affect the values of the $N_{t, k} s$ for the elderly and other existing generations and to assess the impact of such policies on national saving. In a recent study Abel, Bernheim, and Kotlikoff (1990) used CES data to calculate average and marginal propensities to consume of U.S. households by the age of the household head. We intend to use these results to determine the U.S. consumption response to a range of potential intergenerational fiscal policies. A generation's consumption response to the hypothetical policies will simply be calculated as the change in the generation's $N_{1, k}$ multiplied by the corresponding marginal propensity to consume.

\section{HOW DO THE $N_{t, k}$ s ENTER PRIVATE BUDGET CONSTRAINTS?}

The lifetime budget constraint of each generation specifies that the present value of its consumption must equal its current net wealth, plus the present value of its human wealth. plus the present value of its net private intergenerational transfers, less the present value of its net payments to the government, its $N_{t, k^{*}}$ This section shows precisely how the 
$N_{t, k}$ enter private budget constraints and how we can use our estimates on the $N_{1, k} s$ and additional information to infer the extent of net private intergenerational transfers.

For the generation born in year $k$ the year $t$ remaining lifetime budget constraint is

$$
\sum_{s=t}^{k+D}\left[\bar{C}_{s, k}+\bar{I}_{s, k}\right] P_{s, k} \prod_{j=t}^{s} \frac{1}{1+r_{j}}=W_{t, k}+\sum_{s=t}^{k+D} \bar{E}_{s, k} P_{s, k} \prod_{j=l+1}^{s} \frac{1}{1+r_{j}}-N_{i, k}
$$

In (3) the terms $\bar{C}_{s, k} \bar{I}_{s, k}$ and $\bar{E}_{s, k}$ stand, respectively, for the average values in year $s$ of consumption, private net intergenerational transfers, and labor earnings of the generation born in year $k$. The term $W_{i, k}$ stands for the year $\mathrm{t}$ net wealth of the generation born in year $k$. This equation states that the present value of the cohort's projected consumption plus its net intergenerational transfers equals the present value of its resources. The present value of its resources equals, in turn, its net wealth, plus the present value of its labor earnings, less the present value of its net payments to the government, $N_{t, k}$. There are data available to estimate the present value of a cohort's consumption, the present value of its labor earnings, and its current net worth. Hence, in future work we intend to compare our estimates of $N_{t, k}$ with the projected present value of the cohort's remaining lifetime resources. We will also use these data and equation (3) to derive, as a residual, an estimate of the projected present value of the cohort's net private intergenerational transfers.

As mentioned, in our actual calculations we distinguish generations by sex as well as age in 1990. Our calculated age and sex-specific values for the present value of intergenerational transfers include, therefore, intragenerational transfers from males to females. Hence, in determining the magnitude of transfers that are truly intergenerational (across age groups) we add together the calculated private transfers of male and female generations of the same age. This provides us with a statement of the net present value of private transfers given by (received from) all members (both the males and the females) of a given generation to members of other generations.

In the previous section we discussed comparing the $N_{t, k} s$ of future generations with $N_{t, t}$ which is the net lifetime payments of the generation that was born at time $t$. We also discussed comparing the $N_{t, k} s$ of all existing generations under current policy with their respective values under a different policy. These comparisons, which involve differences 
(either across generations or across policies) in $N_{t, k} s$, are invariant to the accounting framework we are adopting, although the absolute values of the $N_{t, k}$ s depend on our accounting framework.

To see this point, consider once again the labeling of social security receipts and payments. Although the U.S. government labels social security contributions as "taxes" and social security benefits as "trans" fers," from the perspective of economic theory one could equally well label social security contributions as "private saving" (invested in government bonds) and label social security benefits as the "return of principal plus interest" on that saving, less an "old age tax" that would be positive or negative depending on whether the social security system was less than or more than actuarially fair in present value. Under either choice of labels the right-hand side of the budget constraint (3) would retain the same value, but the division of the right-hand side between $W_{t}^{p}$ and $N_{k, t}$ would change. It is in this sense that the absolute value of the $N_{k, t} s$ depends on the accounting framework. However, regardless of which way one accounts for (labels) the social security system, the change in the value of $N_{t, k}$ from a policy change, such as a reduction in social security benefits, would be the same. Under the conventional labeling the change in the value of the $N_{t, k} s$ would simply equal the reduction for generation $k$ in the time $t$ present value of their receipts from social security. Under the "private saving less an old age tax ${ }^{\prime \prime}$ labeling, the change in the value of the $N_{1, k} s$ would simply equal the increase for generation $k$ in the time $t$ present value of their old age tax.

Although the change in the value of the $N_{t, k} \mathrm{~s}$ associated with a policy change is invariant to the accounting convention (the choice of labels for government receipts and payments), the same is not true for the government's budget deficit. The same change in policy will lead to different changes in the reported budget deficit depending on one's choice of labels for government receipts and payments. For example, consider the impact of a equal reduction in social security contributions and benefit payments under the two labeling schemes for social security. In the case social security contributions are labeled "taxes" and social security benefits are labeled "transfers," this policy change will have no effect on the budget deficit, since the change in "taxes" equals the change in "transfer" spending. In contrast, if social security contributions are labeled "private saving" and social security benefits are labeled "return of principal plus interest" plus "an old age tax," an equal and simultaneous reduction in contributions and benefit payments will mean a larger "old age tax" for elderly recipients and imply a reduction in the budget deficit. 


\section{CALCULATING THE $N_{t, k}$ s AND OTHER COMPONENTS OF THE GOVERNMENT AND EACH GENERATION'S INTERTEMPORAL BUDGET CONSTRAIN'TS}

\section{A. Data Sources for Calculating Net Payments}

According to equation (2) estimating the values of the $N_{t, s} s$ requires projections of net payments, the $\bar{T}_{s, k} s$ for $D+k \geq s \geq k_{s}$ population projections, the $P_{s, k} s$ for $D+k \geq s \geq k$, and the time path of interest rates. Projections of the population by age and sex are available from the Social Security Administration through 2050, and we have extrapolated these projections through the year 2100 in the course of a study of demographics and saving (Auerbach, Cai, and Kotlikoff, 1990).

We use SIPP data to calculate the average 1984 year values by age and sex of each of the different types of government receipts and payments covered in SIPP. The SIPP sample size is roughly 16,000 U.S. households. The SIPP is a panel survey that reinterviewed respondent households eight times (every 4 months) over the course of 2 years. The first wave of interviews began in July 1983 and ended in July 1985. Thus, for 1984, there is a complete calendar year of SIPP data. The government receipts and payments in the SIPP survey include federal and state income and FICA taxes, Food Stamps, AFDC and WIC benefits, Supplemental Security Income, general relief, unemployment compensation, Social Security retirement, survivor and disability benefits, other welfare, Foster Child Care, and other government transfers. Denton Vaughan (1989) provides a detailed analysis of the improvements in the measurement of government receipts and payments in the SIPP as compared with other surveys such as The Current Population Survey.

The major deficiency with respect to SIPP's coverage of government receipts and payments is with respect to Medicaid and Medicare health care payments. To determine the average amount of Medicare payments by age (the data are not available by sex) for Medicare payments we use Waldo, Sonnefeld, and McKusick's (1989) calculations of average Medicare expenditures by age.

Data on Medicaid expenditures by age and sex will ultimately be obtained from the National Center for Health Services Research's National Medical Care Expenditure Survey for 1987. These data are scheduled to be released later this year. At the moment, however, we assume that the distribution of Medicaid expenditures by age and sex is the same as that of general welfare payments. 


\section{B. Determining Net Payments}

The average values of the receipts and payments by age and sex calculated from SIPP and the Medicare data are only used to determine the values of these receipts and payments by age and sex relative to that of a base age-sex category, which we take to be 40 -year-old males. Given these age-sex relative profiles we determine our initial year (1990) average values of each type of payment and receipt by age and sex by benchmarking against aggregate totals reported in the National Income and Product Account's aggregate values of government receipts and transfers. We then assume that the age and sex-specific average values of these payments and receipts in future years equal those calculated for 1990 adjusted for an assumed growth rate.

To provide an example of this procedure in a simple two-period context where there are only young and old, suppose total receipts of a certain type at a given date equals $\$ 1000$ and suppose we know that the average payment of old people equals twice the average for the young. Also suppose we know that there are 200 young and 150 old. Then the amount paid by each young person $Z$ must satisfy: $\$ 1000=Z \times 200+Z$ $\times 2 \times 150$. Solving this equation for $Z$ and multiplying by 2 gives the amount paid on average by old people. If the growth rate is $g$, then the projected payment of the young (old) $k$ periods from now is $Z \times(1+g)^{k}[2$ $\left.\times Z \times(1+g)^{k}\right)$.

More generally, we denote by $R_{4, i}^{\mathrm{m}}\left(R_{a, i}^{i}\right)$ average value of the $i$ th payment or receipt made by (received by) an age a male (female) in 1984 divided by the average value of the type $i$ payment (receipt) made by $40-$ year-old males in 1984. Let $H_{i, i}$ denote the aggregate revenues (expenditures) of type $i$ received by (made by) the government in year $t$ (1990). Finally, let $\bar{h}_{a, i, t}^{\mathrm{m}}$ and $\bar{h}_{a, i, t}^{\mathrm{t}}$ denote, respectively, the average values for males and females of payment (receipt) $i$ in year $t$. Then we have

$$
H_{\mathrm{jt}}=\bar{h}^{\mathrm{m}}{ }_{40, j, t} \sum_{j=0}^{D}\left[R_{j, i}^{\mathrm{m}}, P_{t, t, j}^{\mathrm{m}}+R_{j, i}^{\mathrm{t}}, P_{t, t-\mathrm{j}}^{\mathrm{t}}\right]
$$

Equation (4) states that total payments (receipts) of type $i$ in year $t$ equals the average value of these payments (receipts) for 40-year-old males times the cross-product of the age-sex profile for payment (receipt) $i$ and the population by age and sex. We use equation (4) to solve for $\bar{h}^{\mathrm{m}}{ }_{40, \mathrm{~s}, t,}$. The values of the $\bar{h}_{a, i, t}^{\mathrm{m}} \mathrm{s} a \neq 40$ and the $\bar{h}_{a, i, t}^{\mathrm{s}} \mathrm{s}$ are obtained by multiplying $\bar{h}_{40, i, t}^{\mathrm{m}}$

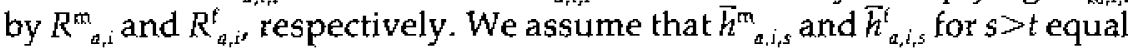
their respective year $t$ values multiplied by an assumed growth factor. 
The term $\bar{T}_{s, k}$ for males (for females) in equation (2) is determined by summing over $i$ the values of $\bar{h}^{m}{ }_{s-k_{i}, i s}\left(\bar{h}_{s-k_{s}, s}\right)$.

Clearly for certain types of payments and receipts, such as Medicare benefits, the choice of the proper growth factor may be particularly difficult. But rather than choose one value, we present results for different growth rate assumptions. The same type of sensitivity analysis applies to the choice of the interest rate to be used in the discounting. Although the absolute magnitude of the terms in the government's intertemporal budget constraint are sensitive to these assumptions, the assessment of the burden being placed on future generations relative to that being placed on current generations happens not to be very sensitive to these assumptions.

\section{The Treatment of Labor Income Taxes}

We determine the relative profile of total labor income by age and sex from the SIPP data and apply this profile to aggregate labor income taxes. The aggregate value of labor income tax payments is calculated as $80.4 \%$ of total federal, state, and local income taxes, where 80.4 is labor's share of net national product. In calculating labor's share of net national product we assume that labor's share of proprietorship and partnership income as well as its share of indirect tax payments equals its share of net national product. The resulting figure for aggregate labor income taxes is $\$ 446.1$ billion.

\section{The Treatment of Contributions for Social Insurance}

We used information on labor earnings in the SIPP to infer the amount of FICA taxes paid by each household member. From these data we then determined the relative profile of FICA tax payments by age and sex. This profile was benchmarked against aggregate social insurance contributions, including contributions by government workers to their pension funds. The 1989 value of aggregate contributions for social insurance is $\$ 476.8$ billion.

\section{E. The Treatment of Capital Income Taxes}

Taxes on capital income require special treatment. There are two related reasons for this. First, unlike other taxes, taxes on capital income may be capitalized into the value of existing (old) assets. Second, the time pattern of income and tax payments may differ. As a result of these features of capital income taxes, such taxes must be attributed with care to ensure that they are assigned to the proper generation. If all forms of capital income were taxed at the same rate, there would be no such problem: alt assets would yield the same rate of return before tax (adjusted for risk) 
and each individual would face a rate of return reduced by the full extent of the tax. However, if tax rates on the income from some assets, typically older ones, are higher than those facing income from new assets (e.g., because of investment incentives targeted toward new investment) a simple arbitrage argument (see, for example, Auerbach and Kotlikoff, 1987. Chapter 9) indicates that the extra tax burden on the old assets should be capitalized into these assets' values, reflecting their less favorable treatment. This suggests that the flow of capital income taxes overstates the burden on new investment. On the other hand, the presence of accelerated depreciation allowances works in the opposite direction, since initial tax payments from new investment understate the long-run tax burden on such investments. Although current tax payments overstate the tax burden on new capital by their inclusion of taxes that are already capitalized in the value of existing assets, the understatement of the burden on new investment works in the opposite direction.

We require a method that calculates the value of capitalized taxes and corrects the flow of taxes for these two measurement problems. The appendix provides such a method. To illustrate the nature of the correction, consider the case of cash-flow taxation in which assets are written off immediately. A well-known result is that the effective marginal capital income tax rate under cash-flow taxation is zero. However, taxes would be collected each year on existing capital assets, and such assets should therefore be valued at a discount. Assigning these taxes to the assets' initial owners, rather than members of future generations who may purchase the assets, is consistent with the fact that such future generations of individuals may freely invest in new assets and pay a zero rate of tax on the resulting income. Our correction to actual tax payments should, in this case, result in a zero tax burden on the income from new assets.

The principle underlying our treatment of intramarginal capital income taxes and the discounting of other payments and receipts at pretax rates of return is that one can express private intertemporal budget constraints in the presence of government behavior as (1) the budget constraint that would prevail in the absence of the government with (2) a single modification to the present value of resources that equals, $N_{\mathrm{t}_{k},}$, the present value of the generation's net payment to the government, i.e., one can express private budgets in terms of pretax prices less net taxes valued at pretax prices. In the case of our adjustment for intramarginal capital income taxes we are simply valuing capital at its pretax price and treating the capitalized value of taxes as another payment required by the government from the owners of that capital.

In allocating capital income taxes we (1) correct our estimate of future 
capital income taxes to account for their inclusion of taxes on old capital and the generational timing of capital income taxes, (2) use equation (4) and the SIPP profile of private net wealth holdings by age and sex to allocate total 1989 taxes on new capital by age and sex, (3) project future capital income taxes by age and sex using the 1989 age- and sex-specific values adjusted for growth, and (4) allocate to 1989 owners of capital as a one time tax payment the 1989 capitalized value of the excess taxation of older capital. The allocation of this one time tax by age and sex is based on the SIPP profile of asset holdings by age and sex. Note that in the budget constraint of each existing generation we value their holdings of existing capital at market value plus the capitalized value of intramarginal taxes.

In these calculations we set aggregate capital income taxes equal to $19.6 \%$ (capital's share of net national product) of total federal, state, and local income taxes, plus federal, state, and local corporate taxes (excluding the profits of the U.S. Federal Reserve System), plus estate taxes. The resulting value of 1989 aggregate capital income taxes is $\$ 234.9$ billion. Using the method described in the Appendix, we estimate that the 1989 flow of capital income taxes overstated the capital income tax burden on new investment by $\$ 6.09$ billion and that the capitalized value of excess taxes on old capital equals $\$ 609$ billion. These estimates are calculated in the following manner. We take the value of nonresidential equipment plus structures plus the value of nonowner occupied housing owned by taxable investors (both of which are reported in the Federal Reserve Flow of Funds for 1989), $\$ 5,488.8$ trillion, and multiply this by $11.1 \%$, our estimate of the tax-induced percentage difference between the market value and replacement cost of these assets. We allocate the $\$ 609$ billion $(\$ 5,488.8 \times .111)$ in capitalized taxes as a one time tax to those age- and sex-specific 1989 cohorts according to the SIPP profile of relative net wealth holdings by age and sex.

\section{F. Including the Present Value of Govermment Seignorage in the $N_{t, k} s$}

Another form of payment to the government is the seignorage it collects on private holdings of money balances. Net of the negligible costs of printing money, the government collects, in each year, resources equal to the real value of new money printed. In holding this money, households forego the nominal rate of return available on other assets.

Our strategy for attributing seignorage to different generations may be illustrated using the analogy of an excise tax on durable goods. Suppose the government levied such an excise tax. Households would then spend more to obtain durables, and would therefore face a higher im- 
puted cost of using them until the durables had depreciated or were sold. If the durable good were sold (tax free) in the future, it would command a price in excess of its replacement cost, reflecting the arbitrage with respect to new durables facing the excise tax. A measure of the net fiscal burden imposed on the household by the excise tax is the tax payment made by the household on purchase less this recoupment of the tax upon sale, discounted to the present. In the same way, we attribute the burden of seignorage to households of particular generations by treating the entire acquisition of money balances as a payment to the government and the disposition of money balances as a transfer from the government. This has the effect of imputing a cost equal to the nominal interest rate on the holding of money balances, and also attributes to all current and future generations taken together a total fiscal burden equal to the present value of government receipts from printing money.

We add the present value of such seignorage payments to the present value of other net payments in forming the $N_{t, k}$ s. Specifically, we project average money balances held by each age- and sex-specific generation through the remainder of its life and add each year's net acquisitions (positive or negative) of the monetary base to the $N_{t, k} s$. As with all our caiculations, we have been careful to benchmark against national aggregates. In this case we have ensured that the sum of age- and sex-specific generation net acquisitions of the monetary base sums to the December 1988 to December 1989 change in aggregate base money, which equals $\$ 21.6$ billion.

\section{G. Including Excise Taxes in the $N_{t, k} s$}

Excise tax payments are not included in the SIPP data. To determine the amount of excise taxes paid by the age- and sex-specific generations we use the CES data. We use these calculations as well to project each generation's annual flow and present value of excise taxes. Our benchmark value of aggregate 1989 excise taxes of $\$ 414.0$ billion equals the 1989 NIPA value of total excise taxes, less total property taxes, plus business property taxes, i.e., we include in excise taxes only those property taxes assessed on business. We use the Department of Commerce's (1987) share of business property tax assessments in total (business plus residential) property tax assessments to divide total property taxes between business and residences. This share is $43.9 \%$. In determining the 1989 NIPA value of total excise taxes we include those state and local property and excise taxes listed in the NIPA accounts as "Personal Tax and Nontax Receipts." We do not, however, include those nontax receipts that are included as part of "Personal Tax and Nontax Receipts" as 
excise taxes. Instead, we treat these items, which include tuition and hospital charges, as a return to government assets.

\section{$H$. Including Residential Property Taxes in the $N_{t, k} s$}

We treat residential property taxes as excise taxes on home ownership and allocate these taxes by age and sex using an age-sex profile of relative house values. This profile was obtained from the SIPP data for 1984. In this calculation house values for married couples were divided evenly between the spouses. As in the case of other taxes, we benchmark average property taxes by age and sex using the 1989 value of total residential property taxes, which equals $\$ 62.4$ billion, and we project future average property tax payments using the 1989 age- and sexspecific averages with an adjustment for growth.

\section{Treatment of Social Security and Other Government Transfers}

We divide total government transfer payments excluding federal, state, and local civil service, railroad retirement, and veterans benefits into six categories: OASDI (including Federal Supplementary Security Income), HI (Medicare), AFDC, General Welfare (including Medicare), UI (unemployment insurance), and Food Stamps (including WIC). We use the SIPP data to determine relative profiles by age and sex of each of these categories of government transfers. To determine average 1989 values of these transfer payments by age and sex we benchmark the relative profiles against the NIPA aggregates using equation (4). The absolute average values of each type of transfer payment by age and sex in future years are assumed to equal their respective 1989 values adjusted for growth. The one exception to this procedure is with respect to future social security benefits. We make a rough adjustment for the impact for the 1983 Social Security amendments on future benefits of the baby boom and subsequent generations. These amendments reduced future social security benefits by (1) phasing in a 2-year delay in the receipt of normal retirement and (2) subjecting an increasing share of social security benefits to federal income taxation. Our adjustment involves reducing the average social security benefits of each new cohort that reaches age 65 in the year 2000 and beyond. The reduction in each year's post-age 65 benefits is $1 \%$ for cohorts who are age 65 in the year 2000 . It is $2 \%$ for cohorts who are age 65 in 2001, 3\% for cohorts who are age 65 in 2002, etc, with a maximum reduction of 15\%, i.e., cohorts who reach age 65 in 2014 or later experience a $15 \%$ reduction in the average annual value of their post-age 64 social security benefits relative to the growth adjusted value of post-age 64 social security benefits prevailing in 1989. 


\section{J. Calculating the Present Value of Government Consumption}

Our procedure for projecting the future path of total government consumption is to decompose total 1990 government consumption expenditure into (1) expenditures on those age 0-24, 25-64, and 65+ and (2) non-age-specific expenditures, such as defense. ${ }^{3}$ We denote year $t$ expenditures on those age 0 to 24 divided by the year $t$ population age 0 to 64 as $\bar{g}_{y, t}$ where $y$ stands for young. We denote $\bar{g}_{m, 2}$ and $\bar{g}_{a, l}$ as the corresponding year $t$ average government consumption expenditures on the middle age (those 25 to 64 ) and old (those 65 and older). Finally, we denote $\dot{g}_{t}$ as the year $t$ level of non-age-specific government expenditure divided by the total year $t$ population. We assume that the values of $\bar{g}_{y, s^{\prime}}$ $\bar{g}_{m, s}{ }_{g_{0, s^{\prime}}}$ and $\vec{g}_{s}$ for $s>f$ equal their respective year $t$ values multiplied by a common growth factor. Total government consumption expenditure in year $s$ is then determined as

$$
G_{s}=\vec{g}_{y, s} P_{y, s}+\bar{g}_{\mathrm{m}, s} P_{\mathrm{m}, \mathrm{s}}+\overline{\mathrm{g}}_{0, s} P_{\mathrm{o}, \mathrm{s}}+\bar{g}_{\mathrm{s}} P_{\mathrm{s}}
$$

where $P_{y, s^{\prime}} P_{m, s^{\prime}} P_{0, s^{\prime}}$ and $P_{s}$ stand for the population of young, middle age, old, and the total population in year $s$. We use the OECD's 1986 division of total U.S. government consumption expenditures among the four expenditure categories plus our benchmark value of aggregate expenditures, $G_{s^{\prime}}$ to determine the values of $\bar{g}_{y_{t},}, \hat{g}_{\mathrm{m}, t}, \bar{g}_{0, t}$ and $\bar{g}_{t}$. The $\mathrm{OECD}^{\prime} \mathrm{s}$ division of U.S. government consumption expenditures was $29.1 \%$ on the young (age 0-24), 6.0\% on the middle age (age 25-64), $7.1 \%$ on the old $(65+)$, and the remaining $57.8 \%$ on the total population. Our measure of $G_{t}$ is the 1989 NIPA value of total government consumption expenditures plus the value of civil service, military, and veterans retirement, medical, and disability benefits. We include these additional payments as part of government consumption rather than as transfer payments because they are part of government compensation

${ }^{3}$ The fact that components of government consumption expenditure are targeted toward specific age groups suggests including the present value of such expenditures in torming the $N_{s, k}$ s and the $C_{s, k}$ in equation (3). In future work we intend to present the generational accounts both including and excluding the present value of age-specific government consumption spending in forming the $N_{t, t}$ s and the $\bar{C}_{s, s}$. However, for the economic, as opposed to accounting questions, of how the $N_{t, s}$ of future generations compare with that of the current newborn generation and how changes in policy will change the values of the $N_{t, k}$ for existing generations, the inclusion or exclusion of age-specific government consumption spending on existing generations is irrelevant, i.e., the analysis of the differential incidence of redistributing the burden across generations of paying for the government's consumption can be conducted holding the generational pattern of government consumption expenditures constant. 
to its employees. The resulting value for 1989 total government consumption expenditure is $\$ 1.154$ trillion.

An important issue that arises in considering government as well as private consumption is the treatment of durables. The proper economic treatment involves imputing rent on private and government durables and including this rent (and excluding expenditures on durables) in private and government consumption, respectively. Except for housing, however, the National Income and Product Accounts treats expenditures on durables as current consumption. Although we follow the NIPA treatment of durables in this paper, our future analysis will adjust for the proper economic treatment of private and government durables expenditures.

\section{K. Determining Government Net Wealth}

Since we want our generational accounts and analysis of different generations' private budget constraints to be consistent with National Income and Product Account data, including the total (federal, state, and local) government deficit, we take as our measure of 1989 total government net wealth net government interest payments divided by the sum of (1) our assumed real interest rate and (2) an assumed $5 \%$ inflation rate." Our measure of government net interest payments is $\$ 79.4$ billion smaller than the NIPA figure of $\$ 131.8$ billion because we categorize state and local nontax receipts as positive capital income earned on state and local assets. Assuming a $6 \%$ real interest rate the 1989 value of government net wealth is $-\$ 571$ billion.

\section{Determining Private Sector Wealth}

The 1984 SIPP data are used to determine the age- and sex-specific relative wealth profile. Specifically, we calculate the weighted average values of net wealth by age and sex for 1984 and normalize these values by the weighted average value of net wealth of 40 -year-old males. This provides values of $Q^{\mathrm{m}}{ }_{a}$ and $Q_{a}^{\mathrm{i}}$, the relative age-sex wealth profile. Total private sector wealth in 1989 can then be written as

$$
W P=\bar{q}^{\mathrm{m}} 40, \sum_{j=0}^{Q}\left[Q_{i}^{\mathrm{m}} P_{t, i-i}^{\mathrm{m}}+Q_{j}^{\mathrm{t}} P_{t, t-i}^{\mathrm{t}}\right]
$$

\footnotetext{
* In future work in which we will measure imputed rent on government durables we will also take account of government tangible assets using measurements reported by Eisner and Pieper (1984) and Boskin et al. (1987).
} 
where $\bar{q}_{40, t}^{\mathrm{m}}$ stands for the average wealth of a 40 -year-old male in year $t$, and $W^{P}$ is total 1989 private net wealth. Equation (6) may be used to solve for $\bar{q}^{\mathrm{m}}{ }_{40, t}$. The corresponding values of $\bar{q}_{a, f}^{\mathrm{m}} a \neq 40$, and $\bar{q}_{\sigma, l}^{l}$ are determined by multiplying $\bar{q}^{\mathrm{m}}{ }_{40, i}$ by $Q^{\mathrm{m}}$ and $Q_{j,}^{i}$ respectively.

In using the SIPP data we distribute household wealth to the owner of that wealth, where the ownership is indicated. In the case of married couples, we allocate half of the household's total wealth to each spouse. We set future values of net wealth by age and sex equal to the 1989 values adjusted for growth.

\section{The Choice of Interest Rate}

The government budget constraint given in (1) depends crucially on the choice of the interest rate $r$ that is used in discounting future flows to and from the government sector. If all such flows were certain and riskless, it would clearly be appropriate to use the government's borrowing rate, essentially a risk-free rate, in our calculations. Given that these flows are only estimated however, which rate is appropriate to use?

The answer to this question depends on what we mean by fiscal balance in the presence of uncertainty. On the one hand, there is a straightforward argument that the government's actual borrowing rate is still appropriate. Suppose, for example, that a future receipt has an expected value of, say, $x$, but that the true value of the receipt may turn out to be higher or lower. If it is higher, the government will have to borrow a bit more; if it is less, less borrowing will be required. Assuming that the government's borrowing rate is not affected by these fluctuations, the discounted values will cancel in a calculation of expected discounted revenue, leaving the discounted value of the expected revenue $x$ in the budget constraint. Thus, if we wish to consider the payments from future generations that we expect will be needed to provide fiscal balance, the procedure based on expected flows discounted with the government's borrowing rate is correct.

However, expected fiscal balance may not be the only valid measure, or even the most informative about fiscal incidence. After all, raising a future individual's fiscal burden by $\$ 100$ in some cases and lowering it by $\$ 100$ with the same probability in others need not be a matter of indifference to the individual if he is risk averse. If the increased burden is associated with other negative news (as will be true, for example, if government revenue needs rise during recessions), then these deviations from expected revenues will not cancel from the taxpayer's perspective. To reflect this, we might wish to discount future receipts with a higher discount rate that accounts for this risk. The effect will be to raise the level of receipts necessary for fiscal balance to be achieved, reflecting 
the fact that the burden of uncertain taxes exceeds their expected value. Likewise, the treatment of government spending and transfers should be adjusted for risk, although one should use the same discount rate only if the fluctuations in such spending have the same risk characteristics as taxes do.

In our simulations below, we make different interest rate assumptions in calculating fiscal balance. This will accommodate the alternative views just discussed. The first approach is to apply a low, risk-free rate to the projected flows, in keeping with the view of fiscal balance as expected balance. The second is to apply a market rate, adjusted for risk, in our discounting of all the flows in the government's budget constraint. This approach is consistent with fiscal balance being satisfied in risk-adjusted terms.

\section{FINDINGS}

\section{A. The Burden on Future Generations}

Tables 1 and 2 contain the generational accounts for males and females for different combinations of growth rate and interest rate assumptions. Tables $1 \mathrm{a}-\mathrm{c}$ and $2 \mathrm{a}-\mathrm{c}$ contain the same information for alternative assumptions about population structure, the treatment of capital income taxation and the discount rate, which we will discuss after reviewing the results in the first two tables.

All of these tables show positive values for the accounts for young and middle age cohorts alive in 1989, indicating that these generations will, on balance, pay more in present value than they receive. For generations of males age 65 and older the net present value of payments is negative. This primarily reflects the fact that older generations, whose members are typically retired, can expect to pay relatively little in labor income taxes and payroll taxes over the rest of their lives, while receiving significant social security medicare and retirement benefits. For females, the generational accounts are negative for ages 55 and over. The younger age at which this occurs for women is attributable to the lower labor force participation rates of women and the fact that many women receive social security benefits as dependents of older spouses.

In Tables 1 and 2 the values of the accounts more than double between age zero and age 25. For example, in the case $g=.0075$ and $r=.06$ (which we take as our "base case") the age zero account for males is $\$ 73.7$ thousand and the age 25 account is $\$ 193.0$ thousand. This simply reflects the fact that 25 year olds are closer to their peak taxpaying years than are newborns. The accounts are most negative around age 75 . For the base case, the age 75 account is $-\$ 41.5$ thousand. 
TABLE 1

Accounts for Age Zero and Future Male Generations (thousands of dollars)

\begin{tabular}{|c|c|c|c|c|c|c|c|c|c|}
\hline \multirow{2}{*}{$\begin{array}{c}\text { Generation's age } \\
\text { in } 1989\end{array}$} & \multicolumn{3}{|c|}{$g=0$} & \multicolumn{3}{|c|}{$g=.0075$} & \multicolumn{3}{|c|}{$g=.015$} \\
\hline & $r=.05$ & $r=.06$ & $r=.07$ & $y=.05$ & $r=.06$ & $r=.07$ & $y=.05$ & $r=.06$ & $r=.07$ \\
\hline 0 & 78.9 & 57.6 & 42.8 & 102.0 & 73.7 & 54.1 & 132.5 & 94.9 & 69.0 \\
\hline 5 & 98.8 & 75.3 & 58.3 & 123.4 & 93.2 & 71.4 & 154.9 & 116.0 & 88.0 \\
\hline 10 & 122.8 & 97.5 & 78.5 & 148.3 & 116.8 & 93.2 & 180.0 & 140.7 & 111.3 \\
\hline 15 & 151.4 & 125.2 & 104.8 & 176.9 & 145.3 & 120.7 & 207.7 & 169.4 & 139.6 \\
\hline 20 & 174.8 & 150.0 & 130.0 & 198.3 & 169.1 & 145.6 & 225.8 & 191.4 & 163.7 \\
\hline 25 & 198.4 & 174.8 & 155.2 & 220.1 & 193.0 & 170.5 & 244.9 & 213.8 & 188.0 \\
\hline 30 & 198.9 & 179.2 & 162.2 & 216.7 & 194.5 & 175.5 & 236.4 & 211.6 & 190.3 \\
\hline 35 & 189.5 & 173.9 & 160.2 & 203.0 & 186.0 & 171.0 & 217.6 & 199.2 & 182.7 \\
\hline 40 & 178.7 & 167.1 & 156.4 & 188.5 & 176.2 & 164.8 & 198.7 & 185.8 & 173.7 \\
\hline 45 & 156.9 & 149.8 & 142.8 & 162.6 & 155.4 & 148.3 & 168.1 & 161.1 & 153.9 \\
\hline 50 & 114.6 & 112.2 & 109.5 & 116.1 & 114.1 & 111.7 & 117.1 & 115.7 & 113.7 \\
\hline 55 & 69.4 & 70.7 & 71.4 & 67.8 & 69.7 & 70.9 & 65.6 & 68.3 & 70.0 \\
\hline 60 & 18.1 & 21.7 & 24.7 & 14.8 & 18.9 & 22.4 & 10.9 & 15.8 & 19.7 \\
\hline 65 & -32.7 & -28.8 & -25.3 & -36.2 & -31.8 & -28.0 & -40.0 & -35.2 & -31.0 \\
\hline 70 & -43.4 & -40.2 & -37.4 & -46.1 & -42.7 & -39.6 & -49.1 & -45.3 & -42.0 \\
\hline 75 & -42.0 & -39.7 & -37.6 & -43.9 & -41.5 & -39.3 & -46.0 & -43.4 & -41.0 \\
\hline 80 & -35.9 & -34.5 & -33.1 & -37.2 & -35.6 & -34.2 & -38.4 & -36.8 & -35.3 \\
\hline 85 & -28.4 & -27.6 & -26.8 & -29.0 & -28.2 & -27.4 & -29.7 & -28.8 & -28.0 \\
\hline 90 & -1.5 & -1.5 & -1.5 & -1.5 & -1.5 & -1.5 & -1.5 & -1.5 & -1.5 \\
\hline $\begin{array}{l}\text { Future } \\
\text { generations }\end{array}$ & 95.9 & 69.6 & 51.1 & 124.4 & 89.5 & 65.1 & 162.6 & 1159 & 83.6 \\
\hline
\end{tabular}


TABLE 1a

Accounts for Age Zero and Future Male Generations with Population Age Distribution Constant after 1989 (thousands of dollars)

\begin{tabular}{|c|c|c|c|c|c|c|c|c|c|}
\hline \multirow{2}{*}{$\begin{array}{c}\text { Generation's age } \\
\text { in } 1989\end{array}$} & \multicolumn{3}{|c|}{$g=0$} & \multicolumn{3}{|c|}{$g=.0075$} & \multicolumn{3}{|c|}{$g=.015$} \\
\hline & $r=.05$ & $r=.06$ & $r=.07$ & $r=.05$ & $r=.06$ & $y=.07$ & $r=.05$ & $r=.06$ & $r=.07$ \\
\hline 0 & 70.0 & 51.8 & 39.0 & 89.5 & 65.6 & 48.9 & 114.9 & 83.5 & 61.6 \\
\hline 5 & 91.5 & 70.7 & 55.4 & 113.0 & 86.6 & 67.2 & 140.3 & 106.6 & 82.0 \\
\hline 10 & 121.4 & 97.7 & 79.6 & 144.9 & 115.8 & 93.7 & 173.9 & 137.9 & 110.7 \\
\hline 15 & 159.1 & 133.5 & 113.3 & 183.7 & 153.2 & 129.0 & 213.1 & 176.5 & 147.7 \\
\hline 20 & 169.2 & 147.4 & 129.5 & 189.7 & 164.3 & 143.5 & 213.5 & 183.7 & 159.6 \\
\hline 25 & 167.7 & 150.2 & 135.5 & 183.7 & 163.8 & 147.0 & 201.9 & 179.1 & 160.0 \\
\hline 30 & 155.4 & 142.0 & 130.5 & 167.4 & 152.4 & 139.5 & 180.7 & 163.9 & 149.5 \\
\hline 35 & 148.6 & 137.9 & 128.4 & 158.0 & 146.2 & 135.8 & 168.2 & 155.3 & 143.9 \\
\hline 40 & 141.9 & 133.5 & 125.8 & 149.2 & 140.1 & 131.8 & 156.9 & 147.1 & 138.3 \\
\hline 45 & 136.7 & 130.3 & 124.3 & 141.9 & 135.3 & 129.0 & 147.3 & 140.5 & 134.0 \\
\hline 50 & 114.7 & 111.5 & 108.2 & 117.1 & 114.0 & 120.8 & 119.3 & 116.4 & 113.3 \\
\hline 55 & 77.5 & 77.8 & 77.6 & 76.9 & 77.6 & 77.8 & 75.9 & 77.1 & 77.7 \\
\hline 60 & 24.7 & 27,2 & 29.2 & 22.5 & 25.3 & 27.6 & 19.8 & 23.1 & 25.8 \\
\hline 65 & -24.3 & -21.4 & -18.9 & -26.8 & -23.6 & -20.9 & -29.5 & -26.0 & -23.0 \\
\hline 70 & -34.8 & -32.5 & -30.4 & -36.8 & -34.3 & -32.1 & -39.0 & -36.3 & -33.8 \\
\hline 75 & -34.9 & -33.2 & -31.6 & -36.4 & -34.6 & -32.9 & -38.0 & -36.0 & -34.2 \\
\hline 80 & -31.1 & -30.0 & -28.9 & -32.1 & -30.9 & -29.7 & -33.1 & -31.8 & -30.6 \\
\hline 85 & -26.0 & -25.3 & -24.7 & -26.6 & -25.9 & -25.2 & -27.2 & -26.4 & -25.7 \\
\hline 90 & -1.5 & -1.5 & -1.5 & -1.5 & -1.5 & -1.5 & -1.5 & -1.5 & -1.5 \\
\hline $\begin{array}{l}\text { Future } \\
\text { generations }\end{array}$ & 84.8 & 66.1 & 52.5 & 104.5 & 80.2 & 62.8 & 130.5 & 98.6 & 76.1 \\
\hline
\end{tabular}


TABLE 1b

Accounts for Age Zero and Future Male Generations with No Intramarginal Capital Income Tax (thousands of dollars)

\begin{tabular}{|c|c|c|c|c|c|c|c|c|c|}
\hline \multirow{2}{*}{$\begin{array}{c}\text { Generation's age } \\
\text { in } 1989\end{array}$} & \multicolumn{3}{|c|}{$g=0$} & \multicolumn{3}{|c|}{$g=.0075$} & \multicolumn{3}{|c|}{$g=.015$} \\
\hline & $r=.05$ & $r=.06$ & $r=.07$ & $r=.05$ & $r=.06$ & $r=.07$ & $r=.05$ & $r=.06$ & $r=.07$ \\
\hline 0 & 79.2 & 57.8 & 42.9 & 102.4 & 74.0 & 54.3 & 133.1 & 95.3 & 69.2 \\
\hline 5 & 99.2 & 75.6 & 58.4 & 123.9 & 93.5 & 71.6 & 155.6 & 116.4 & 88.3 \\
\hline 10 & 123.2 & 97.8 & 78.7 & 148.9 & 117.2 & 93.5 & 180.8 & 141.2 & 111.7 \\
\hline 15 & 151.9 & 125.7 & 105.1 & 177.6 & 145.8 & 121.1 & 208.6 & 170.0 & 140.1 \\
\hline 20 & 175.3 & 150.4 & 130.3 & 199.0 & 169.6 & 146.0 & 226.8 & 192.1 & 164.2 \\
\hline 25 & 198.5 & 174.8 & 155.0 & 220.4 & 193.1 & 170.5 & 245.4 & 214.1 & 188.0 \\
\hline 30 & 198.1 & 178.1 & 161.1 & 216.0 & 193.6 & 174.4 & 235.9 & 210.9 & 189.4 \\
\hline 35 & 187.2 & 171.6 & 157.7 & 200.9 & 183.8 & 168.6 & 215.7 & 197.0 & 180.4 \\
\hline 40 & 175,0 & 163.2 & 152.4 & 184.9 & 172.4 & 160.9 & 195.3 & 182.1 & 169.9 \\
\hline 45 & 151.6 & 144.3 & 137.3 & 157.4 & 150.1 & 142.9 & 163.1 & 155.8 & 148.6 \\
\hline 50 & 107.9 & 105.4 & 102.5 & 109.5 & 107.4 & 104.8 & 110.6 & 109.1 & 106.9 \\
\hline 55 & 61.6 & 62.9 & 63.5 & 60.1 & 62.0 & 63.1 & 58.0 & 60.6 & 62.3 \\
\hline 60 & 10.0 & 13.5 & 16.4 & 6.7 & 10.8 & 14.1 & 2.9 & 7.6 & 11.5 \\
\hline 65 & -40.7 & -36.8 & -33.4 & -44.1 & -39.8 & -36.1 & -47.9 & -43.1 & -39.0 \\
\hline 70 & -50.6 & -47.5 & -44.7 & -53.3 & -49.9 & -46.9 & -56.3 & -52.6 & -49.3 \\
\hline 75 & -48.2 & -45.9 & -43.8 & -50.1 & -47.7 & -45.4 & -52.1 & -49.5 & -47.2 \\
\hline 80 & -41.1 & -39.7 & -38.3 & -42.3 & -40.8 & -39.4 & -43.6 & -42.0 & -40.5 \\
\hline 85 & -33.2 & -32.4 & -31.7 & -33.9 & -33.1 & -32.3 & -34.5 & -33.7 & -32.9 \\
\hline 90 & -6.4 & -6.4 & -6.4 & -6.4 & -6.4 & -6.4 & -6.4 & -6.4 & -6.4 \\
\hline $\begin{array}{l}\text { Future } \\
\text { generations }\end{array}$ & 105.3 & 81.2 & 64.9 & 132.1 & 99.4 & 77.1 & 168.7 & 124.1 & 93.9 \\
\hline
\end{tabular}


TABLE Ic

Accounts for Age Zero and Future Male Generations (thousands of dollars)

\begin{tabular}{|c|c|c|c|c|c|c|c|c|c|}
\hline \multirow{2}{*}{$\begin{array}{l}\text { Generation's age } \\
\text { in } 1989\end{array}$} & \multicolumn{3}{|c|}{$g=0$} & \multicolumn{3}{|c|}{$g=.0075$} & \multicolumn{3}{|c|}{$g=.015$} \\
\hline & $r=.025$ & $r=.03$ & $r=.035$ & $r=.025$ & $y=.03$ & $r=.035$ & $r=.025$ & $r=.03$ & $\gamma=.035$ \\
\hline 0 & 185.1 & 155.0 & 130.2 & 244.3 & 203.8 & 170.5 & 322.9 & 268.8 & 224.2 \\
\hline 5 & 207.2 & 177.5 & 152.5 & 263.7 & 225.3 & 192.9 & 336.3 & 286.6 & 244.8 \\
\hline 10 & 230.6 & 202.1 & 177.6 & 283.4 & 247.7 & 217.0 & 348.9 & 304.4 & 266.0 \\
\hline 15 & 255.1 & 228.6 & 205.4 & 302.9 & 270.7 & 242.5 & 360.1 & 321.3 & 287.2 \\
\hline 20 & 266.9 & 244.2 & 223.8 & 306.8 & 280.1 & 256.2 & 353.1 & 322.0 & 293.9 \\
\hline 25 & 280.8 & 261.1 & 243.2 & 314.4 & 292.0 & 271.5 & 352.2 & 326.9 & 303.7 \\
\hline 30 & 264.0 & 249.0 & 235.0 & 289.0 & 272.5 & 257.0 & 316.0 & 298.1 & 281.1 \\
\hline 35 & 237.4 & 226.7 & 216.6 & 254.5 & 243.2 & 232.4 & 272.3 & 260.6 & 249.2 \\
\hline 40 & 211.9 & 204.9 & 198.0 & 222.7 & 215.7 & 208.7 & 233.2 & 226.4 & 219.4 \\
\hline 45 & 174.5 & 171.2 & 167.8 & 179.1 & 176.2 & 173.0 & 182.6 & 180.4 & 177.8 \\
\hline 50 & 117.5 & 117.4 & 117.1 & 116.7 & 117.3 & 117.5 & 114.8 & 116.2 & 117.1 \\
\hline 55 & 61.8 & 63.9 & 65.7 & 57.7 & 60.5 & 62.8 & 52.4 & 56.0 & 59.0 \\
\hline 60 & 5.2 & 8.4 & 11.2 & -0.2 & 3.4 & 6.7 & -6.6 & -2.3 & 1.5 \\
\hline 65 & -45.4 & -42.5 & -39.8 & -50.4 & -47.1 & -44.1 & -55.9 & -52.2 & -48.8 \\
\hline 70 & -53.1 & -50.9 & -48.9 & -56.7 & -54.3 & -52.1 & -60.6 & -58.0 & -55.6 \\
\hline 75 & -48.8 & -47.3 & -45.9 & -51.2 & -49.6 & -48.1 & -53.8 & -52.1 & -50.4 \\
\hline 80 & -40.1 & -39.2 & -38.4 & -41.5 & -40.6 & -39.7 & -43.0 & -42.1 & -41.1 \\
\hline 85 & -30.5 & -30.1 & -29.6 & -31.2 & -30.8 & -30.3 & -32.0 & -31.5 & -31.0 \\
\hline 90 & -1.5 & -1.5 & -1.5 & -1.5 & -1.5 & -1.5 & -1.5 & -1.5 & -1.5 \\
\hline $\begin{array}{l}\text { Future } \\
\text { generations }\end{array}$ & 225.7 & 188.9 & 158.7 & 299.7 & 249.7 & 208.8 & 399.9 & 332.0 & 276.5 \\
\hline
\end{tabular}


TABLE 2

Accounts for Age Zero and Future Female Generations (thousands of dollars)

\begin{tabular}{|c|c|c|c|c|c|c|c|c|c|}
\hline \multirow{2}{*}{$\begin{array}{c}\text { Generation's age } \\
\text { in } 1989\end{array}$} & \multicolumn{3}{|c|}{$g=0$} & \multicolumn{3}{|c|}{$g=.0075$} & \multicolumn{3}{|c|}{$g=.015$} \\
\hline & $r=.05$ & $r=.06$ & $r=.07$ & $r=.05$ & $y=.06$ & $r=.07$ & $r=.05$ & $r=.06$ & $r=.07$ \\
\hline 0 & 38.9 & 28.7 & 21.4 & 49.5 & 36.4 & 27.0 & 63.0 & 46.3 & 34.2 \\
\hline 5 & 49.1 & 38.1 & 29.8 & 60.2 & 46.5 & 36.2 & 73.7 & 56.9 & 44.1 \\
\hline 10 & 63.2 & 51.2 & 41.8 & 74.8 & 60.4 & 49.1 & 88.5 & 71.4 & 57.8 \\
\hline 15 & 73.3 & 61.9 & 52.6 & 83.9 & 70.7 & 59.8 & 96.0 & 80.9 & 68.2 \\
\hline 20 & 87.9 & 76.9 & 67.5 & 97.9 & 85.5 & 74.8 & 108.7 & 95.0 & 83.1 \\
\hline 25 & 93.1 & 83.5 & 75.1 & 101.4 & 91.0 & 81.7 & 110.0 & 99.1 & 89.0 \\
\hline 30 & 92.5 & 84.8 & 77.7 & 98.8 & 90.9 & 83.3 & 105.0 & 97.1 & 89.3 \\
\hline 35 & 88.1 & 82.6 & 77.2 & 92.2 & 86.9 & 81.5 & 95.8 & 91.1 & 85.8 \\
\hline 40 & 78.8 & 75.8 & 72.4 & 80.6 & 78.2 & 75.1 & 81.6 & 80.2 & 77.6 \\
\hline 45 & 62.9 & 62.7 & 61.7 & 62.1 & 62.9 & 62.6 & 60.3 & 62.4 & 62.9 \\
\hline 50 & 40.3 & 43.0 & 44.6 & 37.2 & 41.0 & 43.4 & 32.8 & 38.1 & 41.6 \\
\hline 55 & 10.5 & 15.6 & 19.5 & 5.4 & 11.7 & 16.5 & -0.8 & 6.9 & 12.8 \\
\hline 60 & -23.9 & -17.8 & -12.7 & -29.7 & -22.5 & -16.7 & -36.3 & -28.0 & -21.2 \\
\hline 65 & -55.0 & -49.1 & -44.0 & -60.3 & -53.7 & -48.0 & -66.3 & -58.8 & -52.4 \\
\hline 70 & -61.2 & -56.4 & -52.0 & -65.5 & -60.2 & -55.4 & -70.2 & -64.3 & -59.1 \\
\hline 75 & -58.7 & -55.1 & -51.8 & -61.8 & -57.9 & -54.4 & -65.1 & -60.9 & -57.1 \\
\hline 80 & -51.3 & -49.0 & -46.8 & -53.3 & -50.8 & -48.5 & -55.3 & -52.7 & -50.3 \\
\hline 85 & -42.9 & -41.7 & -40.6 & -43.9 & -42.7 & -41.5 & -44.9 & -43.6 & -42.4 \\
\hline 90 & -7.4 & -7.4 & -7.4 & -7.4 & -7.4 & -7.4 & -7.4 & -7.4 & -7.4 \\
\hline $\begin{array}{l}\text { Future } \\
\text { generations }\end{array}$ & 47.3 & 34.7 & 25.5 & 60.4 & 44.2 & 32.5 & 77.3 & 56.6 & 41.4 \\
\hline
\end{tabular}


TABLE 2a

Accounts for Age Zero and Future Female Generations with Population Age Distribution Constant after 1989 (thousands of dollars)

\begin{tabular}{|c|c|c|c|c|c|c|c|c|c|}
\hline \multirow{2}{*}{$\begin{array}{c}\text { Generation's age } \\
\text { in } 1989\end{array}$} & \multicolumn{3}{|c|}{$g=0$} & \multicolumn{3}{|c|}{$g=.0075$} & \multicolumn{3}{|c|}{$g=.015$} \\
\hline & $r=.05$ & $r=.06$ & $r=.07$ & $r=.05$ & $r=.06$ & $r=.07$ & $r=.05$ & $r=.06$ & $r=.07$ \\
\hline 0 & 35.5 & 26.4 & 19.8 & 45.0 & 33.3 & 24.9 & 57.2 & 42.1 & 31.3 \\
\hline 5 & 46.8 & 36.6 & 28.9 & 57.2 & 44.4 & 34.8 & 70.0 & 54.1 & 42.2 \\
\hline 10 & 64.4 & 52.6 & 43.4 & 76.0 & 61.7 & 50.6 & 89.7 & 72.6 & 59.1 \\
\hline 15 & 79.5 & 67.7 & 58.1 & 90.6 & 76.8 & 65.6 & 103.4 & 87.3 & 74.2 \\
\hline 20 & 87.3 & 77.0 & 68.3 & 96.6 & 84.9 & 75.1 & 107.1 & 93.9 & 82.7 \\
\hline 25 & 79.7 & 72.1 & 65.6 & 86.4 & 78.0 & 70.7 & 93.7 & 84.5 & 76.4 \\
\hline 30 & 72.8 & 67.1 & 62.1 & 77.6 & 71.5 & 66.0 & 82.6 & 76.2 & 70.3 \\
\hline 35 & 69.3 & 65.0 & 61.0 & 72.7 & 68.3 & 64.1 & 76.1 & 71.8 & 67.4 \\
\hline 40 & 62.8 & 60.1 & 57.3 & 64.8 & 62.3 & 59.5 & 66.5 & 64.3 & 61.7 \\
\hline 45 & 55.7 & 54.7 & 53.4 & 56.0 & 55.5 & 54.5 & 55.7 & 55.9 & 55.3 \\
\hline 50 & 42.9 & 44.3 & 45.0 & 41.0 & 43.3 & 44.5 & 38.4 & 41.6 & 43.6 \\
\hline 55 & 16.9 & 20.8 & 23.8 & 13.0 & 17.8 & 21.5 & 8.3 & 14.2 & 18.7 \\
\hline 60 & -15.8 & -11.2 & -7.4 & -20.0 & -14.7 & -10.3 & -24.9 & -18.8 & -13.8 \\
\hline 65 & -44.1 & -39.8 & -36.1 & -48.0 & -43.2 & -39.0 & -52.2 & -46.9 & -42.3 \\
\hline 70 & -50.4 & -46.8 & -43.6 & -53.6 & -49.6 & -46.1 & -57.0 & -52.7 & -48.9 \\
\hline 75 & -49.3 & -46.6 & -44.1 & -51.7 & -48.7 & -46.1 & -54.1 & -51.0 & -48.2 \\
\hline 80 & -44.5 & -42.6 & -40.9 & -46.0 & -44.1 & -42.2 & -47.7 & -45.6 & -43.7 \\
\hline 85 & -39.3 & -38.3 & -37.3 & -40.2 & -39.1 & -38.1 & -41.1 & -40.0 & -38.9 \\
\hline 90 & -7.4 & -7.4 & -7.4 & -7.4 & -7.4 & -7.4 & -7.4 & -7.4 & -7.4 \\
\hline $\begin{array}{l}\text { Future } \\
\text { generations }\end{array}$ & 43.0 & 33.7 & 26.7 & 52.6 & 40.7 & 32.0 & 65.0 & 49.7 & 38.6 \\
\hline
\end{tabular}


TABLE 2b

Accounts for Age Zero and Future Female Generations with No Intramarginal Capital Income Tax (thousands of dollars)

\begin{tabular}{|c|c|c|c|c|c|c|c|c|c|}
\hline \multirow{2}{*}{$\begin{array}{l}\text { Generation's age } \\
\text { in } 1989\end{array}$} & \multicolumn{3}{|c|}{$g=0$} & \multicolumn{3}{|c|}{$g=.0075$} & \multicolumn{3}{|c|}{$g=.015$} \\
\hline & $r=.05$ & $r=.06$ & $r=.07$ & $r=.05$ & $r=.06$ & $r=.07$ & $r=.05$ & $r=.06$ & $r=.07$ \\
\hline 0 & 39.0 & 28.8 & 21.4 & 49.7 & 36.5 & 27.1 & 63.2 & 46.5 & 34.3 \\
\hline 5 & 49.2 & 38.2 & 29.8 & 60.4 & 46.6 & 36.3 & 74.0 & 57.1 & 44.2 \\
\hline 10 & 63.4 & 51.3 & 41.9 & 75.1 & 60.6 & 49.2 & 88.8 & 71.6 & 58.0 \\
\hline 15 & 73.5 & 62.0 & 52.7 & 84.2 & 70.9 & 60.0 & 96.4 & 81.1 & 68.4 \\
\hline 20 & 88.2 & 77.1 & 67.7 & 98.2 & 85.7 & 75.0 & 109.1 & 95.3 & 83.3 \\
\hline 25 & 93.5 & 83.8 & 75.3 & 101.8 & 91.3 & 81.9 & 110.5 & 99.5 & 89.3 \\
\hline 30 & 92.6 & 84.8 & 77.7 & 99.0 & 90.9 & 83.3 & 105.2 & 97.2 & 89.3 \\
\hline 35 & 87.7 & 82.1 & 76.6 & 91.9 & 86.5 & 81.0 & 95.5 & 90.7 & 85.3 \\
\hline 40 & 77.7 & 74.6 & 71.2 & 79.6 & 77.1 & 73.9 & 80.7 & 79.2 & 76.5 \\
\hline 45 & 61.1 & 60.8 & 59.8 & 60.4 & 61.1 & 60.7 & 58.6 & 60.7 & 61.1 \\
\hline 50 & 37.8 & 40.4 & 42.0 & 34.7 & 38.5 & 40.8 & 30.4 & 35.7 & 39.1 \\
\hline 55 & 7.4 & 12.4 & 16.2 & 2.3 & 8.5 & 13.3 & -3.9 & 3.8 & 9.6 \\
\hline 60 & -27.6 & -21.4 & -16.4 & -33.3 & -26.2 & -20.3 & -39.9 & -31.6 & -24.8 \\
\hline 65 & -58.8 & -52.9 & -47.9 & -64.1 & -57.5 & -51.8 & -70.1 & -62.6 & -56.3 \\
\hline 70 & -65.1 & -60.2 & -55.9 & -69.3 & -64.0 & -59.3 & -74.0 & -68.1 & -63.0 \\
\hline 75 & -62.3 & -58.7 & -55.4 & -65.3 & -61.5 & -58.0 & -68.6 & -64.5 & -60.7 \\
\hline 80 & -54.4 & -52.0 & -49.9 & -56.3 & -53.9 & -51.6 & -58.3 & -55.8 & -53.4 \\
\hline 85 & -44.9 & -43.7 & -42.6 & -45.9 & -44.7 & -43.5 & -46.9 & -45.6 & -44.4 \\
\hline 90 & -7.8 & -7.8 & -7.8 & -7.8 & -7.8 & -7.8 & -7.8 & -7.8 & -7.8 \\
\hline $\begin{array}{l}\text { Future } \\
\text { generations }\end{array}$ & 51.9 & 40.4 & 32.4 & 64.1 & 49.1 & 38.4 & 80.2 & 60.5 & 46.5 \\
\hline
\end{tabular}


TABLE 2c

Accounts for Age Zero and Future Female Generations (thousands of dollars)

\begin{tabular}{|c|c|c|c|c|c|c|c|c|c|}
\hline \multirow{2}{*}{$\begin{array}{c}\text { Generation's age } \\
\text { in } 1989\end{array}$} & \multicolumn{3}{|c|}{$g=0$} & \multicolumn{3}{|c|}{$g=.0075$} & \multicolumn{3}{|c|}{$g=.015$} \\
\hline & $r=.025$ & $r=.03$ & $r=.035$ & $r=.025$ & $r=.03$ & $r=.035$ & $r=.025$ & $r=.03$ & $r=.035$ \\
\hline 0 & 84.6 & 72.5 & 62.0 & 106.5 & 91.8 & 78.8 & 131.5 & 114.8 & 99.4 \\
\hline 5 & 94.5 & 83.0 & 72.7 & 114.5 & 101.2 & 89.1 & 136.2 & 121.8 & 108.1 \\
\hline 10 & 108.5 & 97.5 & 87.5 & 126.8 & 114.7 & 103.3 & 145.4 & 133.2 & 121.0 \\
\hline 15 & 112.9 & 103.7 & 95.2 & 127.4 & 117.9 & 108.6 & 141.1 & 132.2 & 122.9 \\
\hline 20 & 123.0 & 115.4 & 107.9 & 134.4 & 127.1 & 119.5 & 144.1 & 138.1 & 131.0 \\
\hline 25 & 120.7 & 115.1 & 109.5 & 128.3 & 123.5 & 118.2 & 133.5 & 130.5 & 126.1 \\
\hline 30 & 111.7 & 108.3 & 104.6 & 115.5 & 113.3 & 110.2 & 116.4 & 116.2 & 114.6 \\
\hline 35 & 98.8 & 97.5 & 95.6 & 99.2 & 99.2 & 98.3 & 96.5 & 98.7 & 99.3 \\
\hline 40 & 81.0 & 81.6 & 81.6 & 78.3 & 80.4 & 81.4 & 72.7 & 76.8 & 79.4 \\
\hline 45 & 55.9 & 58.6 & 60.4 & 50.0 & 54.1 & 57.2 & 41.2 & 47.4 & 52.1 \\
\hline 50 & 25.2 & 29.6 & 33.1 & 16.8 & 22.5 & 27.3 & 5.7 & 13.3 & 19.6 \\
\hline 55 & -10.5 & -5.1 & -0.3 & -20.5 & -13.8 & -7.9 & -32.6 & -24.4 & -17.2 \\
\hline 60 & -46.1 & -40.7 & -35.8 & -55.6 & -49.2 & -43.6 & -66.6 & -59.2 & -52.5 \\
\hline 65 & -74.7 & -70.1 & -65.8 & -82.6 & -77.4 & -72.6 & -91.6 & -85.6 & -80.1 \\
\hline 70 & -76.7 & -73.2 & -69.9 & -82.6 & -78.7 & -75.1 & -89.1 & -84.8 & -80.8 \\
\hline 75 & -69.6 & -67.2 & -64.9 & -73.6 & -70.9 & -68.5 & -77.8 & -75.0 & -72.3 \\
\hline 80 & -58.0 & -56.6 & -55.2 & -60.3 & -58.8 & -57.3 & -62.8 & -61.2 & -59.6 \\
\hline 85 & -46.2 & -45.5 & -44.9 & -47.3 & -46.6 & -45.9 & -48.5 & -47.7 & -47.0 \\
\hline 90 & -7.4 & -7.4 & -7.4 & -7.4 & -7.4 & -7.4 & -7.4 & -7.4 & -7.4 \\
\hline $\begin{array}{l}\text { Future } \\
\text { generations }\end{array}$ & 103.2 & 88.4 & 75.6 & 130.6 & 112.5 & 96.5 & 162.8 & 141.8 & 122.5 \\
\hline
\end{tabular}


The bottom row of each table, labeled "Future Generations," indicates the present value of amounts that males and females born in 1990 will, on average, pay, assuming that subsequent generations pay this same amount except for an adjustment for growth. For the base case, this amount is $\$ 89.5$ thousand for males. This means that males born in 1990 will be greeted with a bill from all levels of government of $\$ 89.5$ thousand, which is $21.4 \%$ larger than the bill facing 1989 age zero males. Males born in 1991 will face a bill for $\$ 90.2$ thousand, which equals $\$ 89.5$ thousand multiplied by 1.0075 ( 1 plus the growth rate); males born in 1992 will pay $\$ 90.8$ thousand ( $\$ 89.5$ times 1.0075 squared), and so forth. For females born in 1990 , the bill will be $\$ 44.2$ thousand, based on the assumption that future female and male "birth bills" have the same ratio as those of age zero males and females in 1989.

Tables $1 \mathrm{a}-\mathrm{c}$ (males) and $2 \mathrm{a}-\mathrm{c}$ (females) present the same calculations under different assumptions. Tables $1 \mathrm{a}$ and $2 \mathrm{a}$ show the results of assuming that no further demographic change will occur in the United States, i.e., that the population age distribution will be constant after 1990 . These tables are helpful in understanding the fiscal impact of the continuing demographic transition to an older population. These tables indicate that, were the population structure to remain constant, younger generations, those that will bear the brunt of the demographic shift's fiscal burdens, would be better off. This is particularly true for males.

Tables $1 \mathrm{~b}$ and $2 \mathrm{~b}$ demonstrate the importance of our special treatment of capital income taxes. Treating all capital income taxes as marginal taxes on new capital income lowers the fiscal burden on older living generations, since these groups are no longer being assigned the reduction in capital values associated with the inframarginal taxation of old capital. Very young living generations would face a somewhat higher fiscal burden, since these groups hold little capital and will face many years of somewhat higher marginal tax rates. On balance, the reduced capital income taxes facing older living generations and the slightly increased capital income taxes facing younger living generations imply a considerably larger burden on future generations. For the base case parameters the percentage difference in the accounts between age zero generations and future generations is now 34.3 rather than $21.4 \%$. Thus, failure to take account of the capitalization of some capital income taxes causes one to understate the viability of the current tax structure by ignoring the taxes that will be collected on the income from previously acquired capital.

As we indicated above, the choice of which discount rate to use in these tables depends on how one interprets the concept of fiscal balance in the context of uncertainty. The preceding tables have provided estimates for a range of estimates around $6 \%$, corresponding to our "high" 
interest rate assumption. Tables $1 c$ and $2 c$ repeat the exercise of Tables 1 and 2 , but for a lower range of interest rates centered around $3 \%$, closer to the real government borrowing rate. The most significant effect of this change is to increase the measured burdens facing newborns, since these are based largely on discounted payments and receipts that will occur many years hence. However, the same conclusion reached above, that the burdens must rise for future generations, still holds here.

The robustness of this last result is amplified by Table 3 , which presents for a wide range of growth/interest rate combinations the percentage difference in accounts of age zero and future generations. The table indicates that for a range of reasonable interest and growth rate assumptions future generations will face larger fiscal burdens than current age zero generations based on current policy. For the base case, the difference is $21.4 \%$. For the low interest rate case with the same rate of productivity growth $(r=.03, g=.0075)$, the percentage difference is larger, namely $22.5 \%$. More optimistic growth rate assumptions do not materially affect the conclusion of a roughly $20 \%$ larger burden on future generations compared with current generations.

\section{B. The Composition of Generational Accounts}

Appendix Tables 1 and 2 provide for current male and female generations a breakdown of the accounts by different types of receipts and expenditures. The growth and interest rates used in the table are the base case values. All figures are present values. Take the case of 30 -year-old males. On average, the 1989 cohort of 30 -year-old males will pay $\$ 194.5$ thousand dollars in present value to the government over the course of their remaining lives. The $\$ 194.5$ thousand dollar figure reflects the difference between $\$ 222.8$ in present value of payments to the government less $\$ 28.3$ thousand in present value of receipts from the government. The largest source of present value payments is the $\$ 74.4$ thousand in FICA and other payroll taxes, followed by $\$ 69.6$ thousand in labor income taxes, $\$ 38.4$ thousand in capital income taxes, and $\$ 34.2$ thousand in excise taxes. The largest sources of present value receipts are $\$ 14.3$ thousand in social security OASDI benefits, followed by $\$ 5.4$ thousand in general welfare (which includes Medicaid), $\$ 4.6$ thousand in Medicare, and $\$ .9$ thousand in food stamps.

Appendix Tables 3 and 4 further clarify the determinants of these present values. They detail for different 1989 male and female generations the annual flows of payments and receipts (measured in constant 1989 dollars) members of these generations are projected to pay, on average, in specific years in the future. For the 1989 cohort of 30 -year-old males, total 1989 net payments average $\$ 11,271.7$. Their average net pay- 
TABLE 3

Percentage Difference in Accounts of Age Zero and Future Generations

\begin{tabular}{|c|c|c|c|c|c|c|c|c|c|}
\hline $\begin{array}{l}\text { Interest } \\
\text { rate }\end{array}$ & $g=0$ & $g=.0025$ & $g=.005$ & $g=.0075$ & $g=.01$ & $g=.0125$ & $g=.015$ & $g=.0175$ & $g=.02$ \\
\hline 0.03 & 21.93 & 22.09 & 22.30 & 22.54 & 22.83 & 23.16 & 23.53 & 23.94 & 24.39 \\
\hline 0.04 & 21.88 & 21.99 & 22.15 & 22.34 & 22.57 & 22.83 & 23.12 & 23.44 & 23.78 \\
\hline 0.05 & 21.61 & 21.71 & 21.85 & 22.03 & 22.24 & 22.48 & 22.74 & 23.03 & 23.34 \\
\hline 0.06 & 20.89 & 21.02 & 21.19 & 21.39 & 21.62 & 21.88 & 22.16 & 22,45 & 22.77 \\
\hline 0.07 & 19.45 & 19.66 & 19.91 & 20.18 & 20.48 & 20.80 & 21.14 & 21.49 & 21.86 \\
\hline 0.08 & 16.89 & 17.27 & 17.68 & 18.09 & 18.53 & 18.97 & 19.43 & 19.89 & 20.36 \\
\hline 0.09 & 12.74 & 13.40 & 14.06 & 14.73 & 15.38 & 16.04 & 16.69 & 17.34 & 17.98 \\
\hline 0.10 & 6.36 & 7.45 & 8.52 & 9.55 & 10.56 & 11.55 & 12.50 & 13.44 & 14.34 \\
\hline
\end{tabular}


ments 30 years later when they reach age 60 are projected to equal $\$ 25,809$. The tables show clearly the age pattern of the government's various payments and receipts. For example, OASDI benefits for 1989 30 -year-old males average only $\$ 84$, but grow to $\$ 8168.1$ at age 80 .

\section{The Effect of Policy Changes on Generational Accounts}

Tables 4 and $4 \mathrm{a}$ explore the impact on generational accounts of a variety of alternative fiscal policies assuming 6 and $3 \%$ rates of interest respectively. Both tables assume the base case 0.0075 growth rate. The tables compare the generational accounts of newborn and future generations prior to and after the change in policy. Appendix Tables 5 and 6 indicate the impact on the generational accounts of older generations of the various policies assuming base case parameter values; Tables 5a and 6a repeat the analysis assuming a $3 \%$ interest rate.

Capital Gains Tax Cut The first policy considered is the Administration's 1989 capital gains tax cut proposal. In analyzing this proposal we used the Joint Committee on Taxation's (the JCT) revenue estimates; specifically, we raised or lowered projected cohort-specific future average capital income tax payments each year in the future by a factor that would leave total projected capital income tax payments in that year larger or smaller by the amount of revenue gain or loss projected by the JCT. The results of this experiment indicate the Administration's proposal would place an additional burden equal to $\$ 1300$ ( $\$ 700$ ) in present value on each future generation of males (females). Appendix Tables 5 and 6 and $5 \mathrm{a}$ and $6 \mathrm{a}$ indicate that most of the benefits from the capital gains proposal would accrue to currently middle age generations. For example, assuming base case parameters, 45 -year-old males are, on average, projected to receive roughly $\$ 600$ in present value as a result of the capital gains proposal.

No Reduction in Social Security The next policy experiment involves a cancellation of the 1983 Social Security amendments. In this simulation we do not reduce future social security benefits of generations attaining age 65 in the year 2000 and beyond according to the procedure described in Section VI. The impact of reversing the Social Security amendments is particularly strong for middle age women. According to Appendix Table 6 , for base case parameters, 35-year-old women would benefit by $\$ 1,800$ in present value from such a reversal in policy.

Faster Medicare Growth The third policy we consider is faster growth in medicare expenditures. Rather than projecting current spending levels 
TABLE 4

Absolute Values and Percentage Difference in Accounts of Age Zero and Future Male Generations under Altemative Policy Changes $(r=.06, g=.0075)$

\begin{tabular}{|c|c|c|c|c|c|c|c|c|c|}
\hline & \multirow{2}{*}{$\begin{array}{l}\text { Current } \\
\text { policy }\end{array}$} & \multirow{2}{*}{$\begin{array}{l}\text { Capital } \\
\text { gains } \\
\text { tax cut }\end{array}$} & \multirow{2}{*}{$\begin{array}{l}\text { No } \\
\text { reduction } \\
\text { in Social } \\
\text { Security }\end{array}$} & \multirow{2}{*}{$\begin{array}{l}\text { Faster } \\
\text { Medicare } \\
\text { growth }\end{array}$} & \multirow{2}{*}{$\begin{array}{c}\$ 500 \\
\text { billion } 5 \& \mathrm{~L} \\
\text { bailout }\end{array}$} & \multirow{2}{*}{$\begin{array}{c}\text { Slower growth } \\
\text { in government } \\
\text { consumption }\end{array}$} & \multicolumn{3}{|c|}{ Current budget agreement ${ }^{1}$} \\
\hline & & & & & & & $\mathrm{A}$ & $\mathrm{B}$ & $C$ \\
\hline $\begin{array}{l}\text { Age Zero } \\
\text { in } 1989\end{array}$ & 73716 & 73598 & 73325 & 73166 & 73716 & 73716 & 75827 & 75827 & 73819 \\
\hline $\begin{array}{l}\text { Future } \\
\text { generations }\end{array}$ & 89484 & 90754 & 94478 & 105252 & 98930 & 64812 & 49770 & 70180 & 83110 \\
\hline $\begin{array}{l}\text { Percentage } \\
\text { difference }\end{array}$ & 21.4 & 23.3 & 28.8 & 43.9 & 34.2 & -12.1 & -34.4 & -7.4 & 12.6 \\
\hline
\end{tabular}

$1 A_{r}$ all changes are permament; $B$, government expenditure reductions are temporary; $C$, all changes are temporary. 
TABLE 4a

Absolute Values and Percentage Difference in Accounts of Age Zero and Future Generations under Altemative Policy Changes $(r=.03, g=.0075)$

\begin{tabular}{|c|c|c|c|c|c|c|c|c|c|}
\hline & \multirow{2}{*}{$\begin{array}{l}\text { Current } \\
\text { policy }\end{array}$} & \multirow{2}{*}{$\begin{array}{l}\text { Capital } \\
\text { gains } \\
\text { tax cut }\end{array}$} & \multirow{2}{*}{$\begin{array}{l}\text { No } \\
\text { reduction } \\
\text { in Social } \\
\text { Security }\end{array}$} & \multirow{2}{*}{$\begin{array}{l}\text { Faster } \\
\text { Medicare } \\
\text { growth }\end{array}$} & \multirow{2}{*}{$\begin{array}{c}\$ 500 \\
\text { billion } \$ \& \mathrm{~L} \\
\text { bailout }\end{array}$} & \multirow{2}{*}{$\begin{array}{c}\text { Slower growth } \\
\text { in government } \\
\text { consumption }\end{array}$} & \multicolumn{3}{|c|}{ Current budget agreement ${ }^{1}$} \\
\hline & & & & & & & $\mathrm{A}$ & B & C \\
\hline $\begin{array}{l}\text { Age Zero } \\
\text { in } 1989\end{array}$ & 203798 & 203327 & 200606 & 199098 & 203798 & 203798 & 210295 & 210295 & 203914 \\
\hline $\begin{array}{l}\text { Future } \\
\text { generations }\end{array}$ & 249744 & 250820 & 258961 & 272939 & 253944 & 217923 & 203568 & 233219 & 246504 \\
\hline $\begin{array}{l}\text { Percentage } \\
\text { difference }\end{array}$ & 22.5 & 23.4 & 29.1 & 37.1 & 24.6 & 6.9 & -3.2 & 10.9 & 20.5 \\
\hline
\end{tabular}

1 , all changes are permanent; $B$, govermment expenditure reductions are temporary, $C$, all changes are temporary. 
forward at the growth rate of other spending, we assume that medical costs will continue to rise more quickly than other government expenses. In particular we assume that the rate of growth of Medicare expenditures is two percentage points higher than the economy's growth rate for the 20-year period between 1990 and 2010. The experiment produces a sharp jump in the extra burden to be placed on future generations: with base case parameters newborns in 1990 will face an extra burden of $\$ 15,800$ for males and $\$ 7,200$ for females; these figures translate into a $41.6 \%$ larger burden on future generations than on current age zero generations. The simulated Medicare policy provides a sizable benefit to existing older generations. For example, 65-year-old males are estimated to receive an additional $\$ 5,100$ in present value from this policy option.

Given the extraordinary growth in health care spending in recent years, one might well believe that this simulation represents a more realistic view of current policy than our "current policy" projection which assumes only trend growth in Medicare. Clearly, one is free to consider alternative views of what constitutes the expected near and longer term treatment of current generations. Idealiy, one would have information on the public's expectation of the future treatment of current generations to guide the formation of the "current policy" projection. Certainly there is no reason in assessing current policy to restrict oneself to what is actually legislated. We offer our "current policy" projection as an initial benchmark from which to consider possibly more realistic assessments of the future treatment of current generations.

Savings and Loan Bailout The recent savings and loan debacle and bailout illustrates the difficulties of measuring the deficit. The episode included debates about whether bailout financing should be "off-budget" and whether the funds raised should "count" toward the GrammRudman-Hollings targets. Such discussions are reatly irrelevant if one is interested in determining who will bear the costs of this mammoth new government spending program. To model this, we assume that the government issues $\$ 500$ billion dollars of new bonds in 1990 to make good the claims against the insolvent $S \& L s$, and raises taxes only on new generations. We treat the bailout essentially as the undoing of a casualty loss, in that the current generations are assumed to be kept whole by the bailout, i.e., the $\$ 500$ billion simply offsets $\$ 500$ billion in losses due to the insolvencies. Tables 4 and $4 \mathrm{a}$ indicate that this exercise will cost each 1990 newborn male $\$ 9,446$ assuming a $6 \%$ interest rate and $\$ 4,200$ assuming a $3 \%$ interest rate. 
Slower Growth in Government Consumption One of the goals of those who seek to improve the fiscal situation is to "get spending under control." We model this by simulating the effects of zero growth in government consumption for a period of 10 years with the growth in government consumption after the 10-year period occurring at the assumed economywide growth rate. For base case parameters, the impact of this reduced spending is to lower the burden of future generations substantially, by $\$ 24,672$ per male and $\$ 12,200$ per female. The reason this policy has such a large impact can be understood by considering the size of its effect with reference to the terms entering the government's intertemporal budget constraint given in equation (1). Under our base case assumptions the present value of government consumption is $\$ 25.385$ trillion, the present value of payments by existing generations is $\$ 20.998$ trillion, government net wealth is minus $\$ .516$ trillion, and the present value of payments by future generations is $\$ 4.903$ trillion. The simulated 10 -year policy of zero growth in government consumption followed by trend growth means the level of government consumption in year 10 and beyond is lower than under the "current policy" simulation. The effect of this policy is to lower the present value of government consumption by $\$ 1.306$ triliion, which is sizable compared to what would otherwise be the burden on future generations, namely $\$ 4.903$ trillion.

The Govemment's New Budget Deal We examine three alternative views of the recent budget deal. The first alternative, labeled $A$, assumes that the changes made to taxes and spending will be permanent; the second, labeled $B$, assumes that only the reductions in government consumption spending will be permanent; and the third, labeled $C_{t}$ assumes that the provisions will last for only 5 years, after which taxes and government consumption spending will revert to the values they would have had without the budget deal ${ }^{5}$ The results indicate that the importance of the budget deal depends very much on its duration. If the deal is temporary, case $C$, future male generations wili benefit by $\$ 6,374$, while if it is permanent, case $A$, they will benefit by $\$ 39,714$. The loss to current generations is also quite sensitive to the duration of the new policy. If it is kept in place it will, for example, mean a $\$ 4,300$ present value loss to

${ }^{5}$ In these simulations we assume that total taxes are increased in 1991 by $\$ 21.7$ billion, in 1992 by $\$ 32.3$ billion, in 1993 by $\$ 30.4$ billion, in 1994 by $\$ 35.1$ billion, and in 1995 by $\$ 35.1$ billion. The respective annual reductions in total transfer payments are $\$ 3.4, \$ 5.9 . \$ 8.4$, $\$ 11.4$, and $\$ 13.4$ billion. Finally, the respective annual reductions in total government consumption are $\$ 15.8, \$ 32.2, \$ 46.1, \$ 62.7$, and $\$ 73.5$ billion. These aggregate figures as well as the composition of taxes and transfers across the different types of taxes and transfers were obtained from Congressional documents describing the budget deal. 
current age 35-year-old males, while if it is temporary, the loss to current age 35-year-old males is only $\$ 900$. Tables $5,5 a, 6$, and $6 \mathrm{a}$ indicate that the current elderly will pay a considerable share of the total costs to current generations of the new legislation, although this share differs depending on the longevity of the policy.

In understanding the magnitude of the new budget deal, it may help to consider the effects of the budget deal on the components of the government's intertemporal budget constraint. In the simulation(s) in which the budget deal is permanent (temporary) the present value of government consumption falls by $\$ 1.262$ trillion; in the case it is temporary it falls by $\$ 176$ billion. In the permanent simulation the present value burden on existing generations rises by $\$ 825$ billion; in the temporary simulation it rises by $\$ 159$ billion.

\section{SUMMARY}

The ongoing debate about how to define the federal budget deficit is symptomatic of the need for a proper conceptual framework for describing generational policy. Unfortunately, the budget deficit, no matter how it is defined, cannot provide a proper assessment of generational policy. As an alternative to economically arbitrary budget deficits, this paper has provided a set of generational accounts indicating the net present value of payments of existing generations to the government. We have used these accounts and additional data concerning the government's intertemporal budget constraint to assess the magnitude of the fiscal burden being placed on future generations by current generations and to consider the burden on future generations of a set of hypothetical fiscal policies. The findings suggest that unless policy toward existing generations, including those who have just been born, is substantially altered (for example, through a real adherence to the just enacted budget deal), future generations will face a roughly $20 \%$ larger net tax burden over the course of their lifetimes than current newborns.

\section{REFERENCES}

Abel, Andrew, Douglas Bernheim, and Laurence J. Kotlikoff. (1991). "Does the Propensity to Consume Increase with Age?" mimeo.

Auerbach, Alan J. (1983). "Corporate Taxation in the United States." Brookings Papers on Economic Activity.

Auerbach, Alan J. (1987). "The Tax Reform Act of 1986 and the Cost of Capital." Journal of Economic Perspectives.

Auerbach, Alan J., and James Hines. (1987). "Anticipated Tax Changes and the 
Timing of Investment." In Martin S. Feldstein, ed., The Effect of Taxation on Capital Accumulation. Chicago, IL: Chicago University Press.

Auerbach, Alan J., and Laurence J. Kotlikoff. (1987). Dynamic Fiscat Policy. Cambridge: Cambridge University Press.

Auerbach, Alan J., Robert Hagemann, Laurence J. Kotlikoff, and Giuseppe Nicoletti. (1989). "The Economics of Aging Populations: The Case of Four OECD Economies." OECD Staff Papers

Auerbach, Alan J., Jinyong Cai, and Laurence J. Kotlikotf. (1990). "U.S. Demographics and Saving: Predictions of Three Saving Models." Carnegie-Rochester Conference Series on Public Policy, in press.

Boskin, Michael J., Mark S. Robinson, and A. M. Huber. (1987). "Government Saving, Capital Formation, and Wealth in the United States, 1947-85." NBER working paper No. 2352, August.

The Economic Report of the President 1982. (1982). Washington, DC: U.S. Government Printing Office.

Eisner, Robert, and Paul J. Pieper. (1984). "A New View of the Federal Debt and Budget Deficits." American Economic Review 74(1), 11-29.

Feldstein, Martin S. (1974). "Social Security, Induced Retirement, and Aggregate Capital Accumulation," Journal of Political Economy, 82(5), 905-26.

Hamilton, James D., and Marjorie A. Flavin. (1986). "On the Limitations of Government Borrowing: A Framework for Empirical Testing. "American Economic Reziew 76, 808-819.

Kotlikotf, Laurence J. (1984). "Taxation and Savings-A Neoclassical Perspective." Journal of Economic Literature, 1576-1629.

Kotlikoff, Laurence J. (1988). "The Deficit Is Not a Meaningful Measure of Fiscal Policy." Science, 791-794.

Kotlikoft, Laurence J. (1989). "From Deficit Delusion to the Fiscal Balance RuleLooking for a Sensible Way to Measure Fiscal Policy." NBER working paper, March.

Vaughan, Denton R. (1989). "Reflections on the Income Estimates from the Initial Panel of the Survey of Income and Program Participation (SIPP)." Department of Health and Human Services, Social Security Administration Office of Policy Research and Statistics, September.

Waldo, Daniel R., Sally T. Sonnefeld, and David R. McKusick. (1989). "Health Expenditures by Age Group, 1977 and 1987." Health Care Financing 10(4).

Wilcox, David W. (1989). "The Sustainability of Government Deficits: Implications of the Present Value Borrowing Constraint." Journal of Money, Credit and Banking 21, 291-306.

U.S. Department of Commerce, Bureau of the Census. (1987). 1987 Census of Governments' Taxable Property Values. Washington, DC: U.S. Government Printing Office.

\section{APPENDIX: THE ALLOCATION OF CAPITAL INCOME TAXES}

As mentioned in the text, there are two related problems with using capital income taxes as measured to determine the burden of capital income taxation. First, existing assets may have excess future taxes capitalized into their values; such taxes should not be assigned to new inves- 
tors even if they occur in the future. On the other hand, the timing of payments of taxes from new investment may have a different pattern than would an income tax, meaning that the ratio of current annual tax payments to income may not provide an accurate measure of the effective marginal tax rate facing new investment.

In this appendix we derive the formula used to calculate the capitalized value of taxes on existing capital and the correction needed to transform total capital income tax payments into an estimate of capital income tax payments on new investment. Our formula is based on the user cost of capital approach (see, for example, Auerbach, 1983), which assumes that the marginal product of capital equals the user cost of capital, $C$, where

$$
C=(r+\delta)(1-\tau z) /(1-\tau)
$$

where $\gamma$ is the investor's required after-tax return, $\delta$ is the investment's economic rate of depreciation, $\tau$ is the investor's marginal tax rate, and $z$ is the present value of depreciation allowances. We wish to calculate two measures. The first, which we denote by $Q$, is the tax-based discount on old capital, which equals the difference between tax savings from depreciation allowances per unit of new capital and those available per unit of existing capital:

$$
Q=\tau\left(z-z^{a}\right)
$$

where $z^{\circ}$ is the present value of depreciation allowances per unit of old capital.

Measured capital income tax payments are not based on the effective rate of tax on new capital $m$, where

$$
m=\frac{C-(r+\delta)}{C-\delta}
$$

Instead they are based on an average tax rate, $\alpha$, where

$$
\alpha=\frac{\tau(C-b)}{C-\delta}
$$

and $b$ is the average current depreciation deduction per unit of total capital. Comparing (A3) and (A4) indicates that we must correct measured taxes per unit of capital by subtracting from $\alpha(C-\delta)$ the term $\Delta$, where 


$$
\Delta=(\alpha-m)(C-\delta)
$$

To calculate the terms $z^{\circ}$ in (A2) and $b$ in (A4) we must consider past patterns of investment. Assume investment grows at rate $n$. Then at date 0 (the present) the nominal amount of capital purchased at date $-s$ was $I_{0} e^{-(n+m)}$, where $\pi$ is the inflation rate. If this investment has been written off at the constant geometric rate $\psi$, the asset at date 0 has a basis of $I_{0} e^{-\{n+m s} e^{-\psi t 5}$ and receives depreciation allowances of $\psi$ times this basis. Thus total allowances on the existing capital stock $K$ are

$$
b K=\psi_{0} \int^{\infty} I_{0} e^{-(n+\pi) s} e^{-\psi s} d s=\frac{\psi}{n+\pi+\psi} I_{0}
$$

Since the capital stock equals the sum of depreciated net investment we have

$$
K=\int_{0}^{\infty} I_{0} e^{-n s} e^{-\delta s} d s=\frac{1}{n+\delta} I_{0}
$$

Equations (A6) and (A7) imply

$$
b=\frac{\psi(n+\delta)}{n+\pi+\psi}
$$

The present value of all depreciation allowances on old capital equals the basis of each vintage multiplied by the present value of remaining depreciation deductions on that vintage, or

$$
\begin{aligned}
z^{0} & =\frac{1}{K_{0}} \int_{0}^{ \pm} l_{0} e^{-(n+m) s} e^{-\psi s} \int_{0}^{\infty} e^{-(r+\pi) \psi} \psi e^{-\psi \nu} d \nu d s \\
& =\frac{\psi}{r+\pi+\psi} \frac{I_{0}}{K(n+\pi+\psi)}=\frac{\psi}{r+\pi+\psi n+\pi+\psi} \underbrace{n+\delta}_{n+\delta}=\hat{z} \frac{n+\delta}{n+\pi+\psi}
\end{aligned}
$$

where $z$ is the present value of depreciation allowances per unit of depreciated basis.

Substituting (A3), (A4), and (A8) into (A5) yields

$$
\Delta=(r+\delta) \tau z-\frac{(r+\pi+\psi)(n+\delta)}{n+\pi+\psi} \tau \hat{z}
$$


Substituting (A9) into (A2) implies

$$
Q=\tau z-\tau \frac{n+\delta}{n+\pi+\psi}
$$

Expressions (A10) and (A11) may be simplified if we make the realistic (under current tax law) assumption that $\hat{z}=z$, thus,

$$
\Delta=(r+\delta) \tau z\left[1-\frac{(r+\pi+\psi)(n+\delta)}{(n+\pi+\psi)(r+\delta)}\right]
$$

and

$$
Q=\tau z\left(1-\frac{n+\delta}{n+\pi+\psi}\right)
$$

We assume that $\delta=.08$ and $n=.03$. These values are roughly consistent with the average depreciation rates and past growth rates for equipment and structures (see Auerbach and Hines, 1987). We further assume for purposes of these calculations that $r=.04$. For these values and for an inflation rate of $4 \%$ depreciation allowances [the right-hand side of (A14)] provide roughly the same present value as true economic depreciation [the left-hand side of (A14)].

$$
\frac{\delta}{r+\delta}=\frac{\psi}{r+\pi+\psi}=z
$$

When $r=\pi=.04$ and $\delta=.08$, we have from (A14) that $\psi=.16$. For our calculation of the actual value of $z$ based on this value of $\psi$ we assume $\pi=.05$ to maintain consistency with our other calculations. (Using $\pi=.04$ rather than .05 has no important impact on the results.) In addition, we assume that the tax rate $\tau$ equals .32. This value is less than the statutory rate of .34 with the difference reflecting the small difference between corporate and personal statutory rates. These assumptions lead to the values $\Delta=.00111$ and $Q=.111$. This value of $Q$ is consistent with earlier direct calculations based on tax provisions similar to those enacted in 1986 (Auerbach and Hines, 1987). These fractions are multiplied by $\$ 5,488.8$ billion, the value of depreciable assets held by taxable investors in 1989 to arrive at the numbers cited in the text, viz., a $\$ 6.09$ billion subtraction from current total capital income taxes and a $\$ 609$ billion capitalized burden on old capital. 


\section{APPENDIX TABLE 1}

The Composition of Male Generational Accounts $(r=.06, g=.0075)$

\begin{tabular}{|c|c|c|c|c|c|c|c|c|c|c|c|c|c|}
\hline \multirow{4}{*}{$\begin{array}{l}\text { Genera- } \\
\text { tion's age } \\
\text { in } 1989\end{array}$} & \multirow{4}{*}{$\begin{array}{l}\text { Net } \\
\text { payment }\end{array}$} & \multicolumn{12}{|c|}{$\begin{array}{l}\text { Present values of receipts and payments } \\
\text { (thousands of dollars) }\end{array}$} \\
\hline & & \multicolumn{6}{|c|}{ Paymenis } & \multicolumn{6}{|c|}{ Receipts } \\
\hline & & \multirow{2}{*}{$\begin{array}{l}\text { Labor } \\
\text { Income } \\
\text { taxes }\end{array}$} & \multirow{2}{*}{$\begin{array}{l}\text { FICA } \\
\text { taxes }\end{array}$} & \multirow{2}{*}{$\begin{array}{l}\text { Excise } \\
\text { taxes }\end{array}$} & \multirow{2}{*}{$\begin{array}{c}\text { Capital } \\
\text { income } \\
\text { taxes }\end{array}$} & \multirow{2}{*}{$\begin{array}{l}\text { Seignor- } \\
\text { age }\end{array}$} & \multirow{2}{*}{$\begin{array}{l}\text { Property } \\
\text { taxes }\end{array}$} & \multirow[b]{2}{*}{ OASDI } & \multirow[b]{2}{*}{$\mathrm{HI}$} & \multicolumn{2}{|c|}{ Welfare } & \multirow[b]{2}{*}{ UI } & \multirow{2}{*}{$\begin{array}{l}\text { Food } \\
\text { Stamps }\end{array}$} \\
\hline & & & & & & & & & & AFDC & General & & \\
\hline 0 & 73.7 & 24.8 & 26.5 & 22.9 & 9.5 & 0.0 & 1.6 & 4.5 & 1.1 & 0.3 & 4.4 & 1.0 & 0.3 \\
\hline 5 & 93.2 & 31.8 & 34.0 & 26.3 & 12.2 & 0.1 & 2.0 & 5.5 & 1.5 & 0.4 & 4.3 & 1.2 & 0.4 \\
\hline 10 & 116.8 & 40.8 & 43.6 & 29.8 & 15.6 & 0.1 & 2.6 & 6.7 & 1.9 & 0.5 & 4.6 & 1.6 & 0.5 \\
\hline 15 & 145.3 & 52.2 & 55.8 & 32.8 & 20.0 & 0.1 & 3.3 & B. 1 & 2,4 & 0.6 & 5.1 & 2.0 & 0.7 \\
\hline 20 & 169.1 & 61.9 & 66.2 & 33.9 & 24.8 & 0.1 & 4.1 & 9.5 & 2.9 & 0.7 & 5.3 & 2.4 & 0.8 \\
\hline 25 & 193.0 & 70.3 & 75.1 & 35.8 & 32.4 & 0.1 & 5.3 & 12.0 & 3.8 & 0.9 & 5.6 & 2.6 & 0.9 \\
\hline 30 & 194.5 & 69.6 & 74.4 & 34.2 & 38.4 & 0.1 & 6.1 & 14.3 & 4.6 & 0.8 & 5.4 & 2.3 & 0.9 \\
\hline 35 & 186.0 & 65.2 & 69.7 & 32.0 & 43.8 & 0.0 & 6.9 & 17.2 & 5.7 & 0.6 & 5.2 & 2.0 & 0.8 \\
\hline 40 & 176.2 & 60.9 & 65.1 & 30.5 & 49.8 & 0.0 & 7.6 & 21.9 & 7.4 & 0.5 & 5.3 & 1.8 & 0.7 \\
\hline 45 & 155.4 & 54.4 & 58.1 & 28.7 & 54.2 & 0.0 & 7.8 & 29.8 & 10.0 & 0.4 & 5.5 & 1.5 & 0.6 \\
\hline 50 & 114.1 & 42.1 & 45.0 & 24.4 & 52.1 & 0.0 & 7.1 & 37.1 & 12,4 & 0.3 & 5.4 & 1.1 & 0.5 \\
\hline 60 & 18.9 & 20.2 & 21.5 & 17.9 & 44.1 & 0.0 & 6.1 & 62.6 & 22.0 & 0.1 & 5.6 & 0.3 & 0.3 \\
\hline 65 & -31.8 & 9.1 & 9.7 & 14.7 & 37.0 & 0.0 & 5.4 & 71.2 & 30.7 & 0.0 & 5.6 & 0.0 & 0.2 \\
\hline 70 & -42.7 & 4.0 & 4.3 & 11.9 & 29.3 & 0.0 & 4.5 & 61.9 & 29.6 & 0.0 & 4.9 & 0.0 & 0.2 \\
\hline 75 & -41.5 & 1.8 & 2.0 & 9.5 & 22.5 & 0.0 & 3.7 & 48.9 & 27.9 & 0.0 & 4.1 & 0.0 & 0.1 \\
\hline 80 & -35.6 & 0.6 & 0.6 & 7.5 & 17.2 & 0.0 & 3.0 & 36.9 & 24.4 & 0.0 & 3.0 & 0.0 & 0.1 \\
\hline 85 & -28.2 & 0.0 & 0.0 & 6.1 & 14.3 & 0.0 & 2.4 & 28.2 & 20.9 & 0.0 & 1.8 & 0.0 & 0.1 \\
\hline 90 & -1.5 & 0.0 & 0.0 & 1.2 & 6.7 & 0.0 & 0.5 & 5.4 & 4.2 & 0.0 & 0.2 & 0.0 & 0.0 \\
\hline $\begin{array}{l}\text { Future } \\
\text { Generations }\end{array}$ & 89.5 & & & & & & & & & & & & \\
\hline
\end{tabular}


APPENDIX TABLE 2

The Composition of Female Generational Accounts $(r=.06, g=.0075)$

\begin{tabular}{|c|c|c|c|c|c|c|c|c|c|c|c|c|c|}
\hline \multirow{4}{*}{$\begin{array}{l}\text { Genera- } \\
\text { tion's age } \\
\text { in } 1989\end{array}$} & \multirow{4}{*}{$\begin{array}{l}\text { Net } \\
\text { payment }\end{array}$} & \multicolumn{12}{|c|}{$\begin{array}{c}\text { Present values of receipts and poyments } \\
\text { (thousands of dollars) }\end{array}$} \\
\hline & & \multicolumn{6}{|c|}{ Payments } & \multicolumn{6}{|c|}{ Receipts } \\
\hline & & \multirow{2}{*}{$\begin{array}{l}\text { Labor } \\
\text { income } \\
\text { taxes }\end{array}$} & \multirow{2}{*}{$\begin{array}{l}\text { FICA } \\
\text { taxes }\end{array}$} & \multirow{2}{*}{$\begin{array}{l}\text { Excise } \\
\text { taxes }\end{array}$} & \multirow{2}{*}{$\begin{array}{c}\text { Capital } \\
\text { income } \\
\text { taxes }\end{array}$} & \multirow{2}{*}{$\begin{array}{l}\text { Seignor- } \\
\text { age }\end{array}$} & \multirow{2}{*}{$\begin{array}{l}\text { Property } \\
\text { taxes }\end{array}$} & \multirow[b]{2}{*}{ OASDI } & \multirow[b]{2}{*}{$\mathrm{HI}$} & \multicolumn{2}{|c|}{ Welfare } & \multirow[b]{2}{*}{ UI } & \multirow{2}{*}{$\begin{array}{l}\text { Food } \\
\text { Stamps }\end{array}$} \\
\hline & & & & & & & & & & $\mathrm{AFDC}$ & General & & \\
\hline 0 & 36.4 & 14.0 & 14.9 & 20.2 & 3.5 & 0.0 & 2.1 & 5.0 & 1.5 & 2.3 & 7.8 & 0.4 & 1.3 \\
\hline 5 & 46.5 & 17.7 & 18.9 & 23.0 & 4.5 & 0.0 & 2.6 & 6.1 & 1.9 & 2.9 & 7.2 & 0.6 & 1.7 \\
\hline 10 & 60.4 & 23.3 & 24.9 & 27.2 & 5.9 & 0.1 & 3.5 & 7.5 & 2.5 & 3.8 & 7.8 & 0.7 & 2.2 \\
\hline 15 & 70.7 & 28.1 & 30.1 & 29.0 & 7.2 & 0.1 & 4.2 & 8.6 & 3.0 & 4.6 & 8.2 & 0.9 & 2.6 \\
\hline 20 & 85.5 & 34.8 & 37.2 & 32.2 & 9.3 & 0.0 & 5.4 & 10.9 & 3.9 & 5.2 & 9.2 & 1.1 & 3.3 \\
\hline 25 & 91.0 & 36.3 & 38.8 & 33.2 & 11.7 & 0.0 & 6.5 & $\$ 3.1$ & 4.8 & 4.5 & 9.0 & 1.1 & 3.0 \\
\hline 30 & 90.9 & 35.1 & 37.5 & 33.1 & 14.9 & 0.0 & 7.4 & 15.7 & 6.1 & 3.5 & 8.5 & 1.0 & 2.4 \\
\hline 35 & 86.9 & 32.9 & 35.2 & 32.1 & 18.3 & 0.0 & 8.1 & 18.6 & 7.7 & 2.5 & 8.2 & 0.9 & 1.9 \\
\hline 40 & 78.2 & 29.7 & 31.7 & 30.1 & 21.4 & 0.0 & 8.6 & 21.9 & 9.8 & 1.7 & 7.8 & 0.7 & 1.4 \\
\hline 45 & 62.9 & 25.4 & 27.2 & 27.4 & 23.8 & 0.0 & 8.9 & 27.0 & 12.6 & 1.0 & 7.6 & 0.6 & 1.0 \\
\hline 50 & 41.0 & 20.4 & 21.8 & 24.2 & 25.0 & 0.0 & 8.9 & 34.0 & 16.3 & 0.6 & 7.3 & 0.4 & 0.7 \\
\hline 55 & 11.7 & 14.9 & 15.9 & 20.8 & 24.9 & 0.0 & 8.7 & 43.9 & 21.3 & 0.2 & 7.2 & 0.3 & 0.5 \\
\hline 60 & -22.5 & 9.3 & 9.9 & 17.4 & 23.4 & 0.0 & 8.2 & 55.1 & 27.8 & 0.0 & 7.2 & 0.2 & 0.4 \\
\hline 65 & -53.7 & 4.8 & 5.1 & 14.2 & 20.8 & 0.0 & 7.6 & 61.2 & 37.4 & 0.0 & 7.2 & 0.1 & 0.4 \\
\hline 70 & -60.2 & 2.0 & 2.2 & 11.5 & 17.3 & 0.0 & 6.9 & 56.5 & 36.8 & 0.0 & 6.5 & 0.0 & 0.3 \\
\hline 75 & -57.9 & 0.7 & 0.7 & 9.1 & 13.2 & 0.0 & 6.0 & 47.4 & 34.5 & 0.0 & 5.5 & 0.0 & 0.3 \\
\hline 80 & -50.8 & 0.0 & 0.0 & 7.2 & 8.8 & 0.0 & 5.1 & 37.4 & 29.9 & 0.0 & 4.5 & 0.0 & 0.2 \\
\hline 85 & -42.7 & 0.0 & 0.0 & 5.8 & 4.5 & 0.0 & 4.2 & 28.7 & 24.7 & 0.0 & 3.6 & 0.0 & 0.2 \\
\hline 90 & -7.4 & 0.0 & 0.0 & 1.0 & 0.4 & 0.0 & 0.7 & 4.7 & 4.2 & 0.0 & 0.6 & 0.0 & 0.0 \\
\hline $\begin{array}{l}\text { Future } \\
\text { generations }\end{array}$ & 44.2 & & & & & & & & & & & & \\
\hline
\end{tabular}


APPENDIX TABLE 3

The Components of Male Generational Accounts ( $r=.06, g=.0075)$

\begin{tabular}{|c|c|c|c|c|c|c|c|c|c|c|c|c|c|c|}
\hline \multirow{3}{*}{\multicolumn{2}{|c|}{$\begin{array}{c}\text { Cohort that } \\
\text { is age } 0 \\
\text { in } 1989\end{array}$}} & \multirow{4}{*}{$\begin{array}{c}\text { Net } \\
\text { payment }\end{array}$} & \multicolumn{12}{|c|}{ Average antutal values of receipts and payments } \\
\hline & & & \multicolumn{6}{|c|}{ Payments } & \multicolumn{6}{|c|}{ Receipts } \\
\hline & & & \multirow{2}{*}{$\begin{array}{l}\text { Labor } \\
\text { income } \\
\text { taxes }\end{array}$} & \multirow{2}{*}{$\begin{array}{l}\text { FiCA } \\
\text { taxes }\end{array}$} & \multirow{2}{*}{$\begin{array}{l}\text { Excise } \\
\text { taxes }\end{array}$} & \multirow{2}{*}{$\begin{array}{c}\text { Capital } \\
\text { income } \\
\text { taxes }\end{array}$} & \multirow{2}{*}{$\begin{array}{l}\text { Seignor- } \\
\text { age }\end{array}$} & \multirow{2}{*}{$\begin{array}{c}\text { Property } \\
\text { taxes }\end{array}$} & \multirow[b]{2}{*}{ OASDI } & \multirow[b]{2}{*}{ HII } & \multicolumn{2}{|c|}{ Welfare } & \multirow[b]{2}{*}{ UI } & \multirow{2}{*}{$\begin{array}{l}\text { Food } \\
\text { Stamps }\end{array}$} \\
\hline Age & Y'ear & & & & & & & & & & AFDC & General & & \\
\hline 0 & 1989 & 225.9 & 0.0 & 0.0 & 501.4 & 0.0 & 0.0 & 0.0 & 32.2 & 0.0 & 0.0 & 243,3 & 0.0 & 0.0 \\
\hline 10 & 1999 & 659.3 & 0.0 & 0.0 & 867.5 & 0.0 & 0.0 & 0.0 & 72.3 & 0.0 & 0.0 & 136.0 & 0.0 & 0.0 \\
\hline 20 & 2009 & 4434.6 & 1467.3 & 1568.4 & 1600.2 & 183.0 & 14.5 & 4.3 & 84.5 & 0.0 & 9.1 & 224.7 & 68.3 & 16.6 \\
\hline 30 & 2019 & 14104.0 & 4461.1 & 4768.4 & 2307.5 & 3214.9 & 6.6 & 130.8 & 105.5 & 0.0 & 75.3 & 337,5 & 202.5 & 64.4 \\
\hline 40 & 2029 & 24218.5 & 6085.1 & 6504.3 & 2755.2 & 9246.0 & 4.1 & 493.2 & 162.3 & 0.0 & 69.5 & 358.7 & 198.4 & 80.4 \\
\hline 50 & 2039 & 31345.6 & 6336.7 & 6773.2 & 2868.5 & 15876.5 & 2.1 & 688.8 & 488.7 & 0.0 & 52.1 & 394.9 & 192.4 & 72.1 \\
\hline 60 & 2049 & 32294.1 & 5652.7 & 6042.1 & 2715.4 & 19621.5 & 1.7 & 806.5 & 1784.5 & 0.0 & 32.4 & 538.2 & 139.4 & 51.4 \\
\hline 70 & 2059 & 7454.7 & 1370.5 & 1464.9 & 2466.9 & 18162.6 & 2.4 & 895.5 & 10976.4 & 4954.7 & 8.4 & 932.0 & 0.0 & 36.6 \\
\hline 80 & 2069 & -754.0 & 410.2 & 438.5 & $2324-4$ & 13721.6 & 1.2 & 920.2 & 10220.5 & 7226.0 & 0.0 & 1088.3 & 0.0 & 35.3 \\
\hline 90 & 2079 & -1421.1 & 0.0 & 0.0 & 2404.6 & 13121.9 & -6.3 & 916.3 & 9073.6 & 8279.8 & 0.0 & 469.3 & 0.0 & 34.9 \\
\hline \multicolumn{2}{|c|}{$\begin{array}{c}\text { Cohort thaf } \\
\text { is age } 10 \\
\text { in } 1989 \\
\end{array}$} & \multirow{2}{*}{$\begin{array}{c}\text { Net } \\
\text { payment }\end{array}$} & \multirow{2}{*}{$\begin{array}{l}\text { Labos } \\
\text { income } \\
\text { taxes }\end{array}$} & \multirow{2}{*}{$\begin{array}{l}\text { FICA } \\
\text { taxes }\end{array}$} & \multirow{2}{*}{$\begin{array}{l}\text { Excise } \\
\text { taxes }\end{array}$} & \multirow{2}{*}{$\begin{array}{c}\text { Capital } \\
\text { income } \\
\text { taxes }\end{array}$} & \multirow{2}{*}{$\begin{array}{l}\text { Seignor- } \\
\text { age }\end{array}$} & \multirow{2}{*}{$\begin{array}{c}\text { Property } \\
\text { taxes }\end{array}$} & \multirow[b]{2}{*}{ OASDI } & \multirow[b]{2}{*}{ HI } & \multicolumn{2}{|c|}{ Welfare } & \multirow[b]{2}{*}{ UI } & \multirow{2}{*}{$\begin{array}{c}\text { Food } \\
\text { Stamps }\end{array}$} \\
\hline Age & Year & & & & & & & & & & AFDC & General & & \\
\hline 10 & 1989 & 611.0 & 0.0 & 0.0 & 805.1 & 0.0 & 0.0 & 0.0 & 67.1 & 0.0 & 0.0 & 126.2 & 0.0 & 0.0 \\
\hline 20 & 1999 & 4115.3 & 1361.7 & 1455.5 & 1485.0 & 169.8 & 13.5 & 4.0 & 78.4 & 0.0 & 8.5 & 208.5 & 63.4 & 15.4 \\
\hline 30 & 2009 & 13088.5 & 4139.9 & 4425.1 & 2141.3 & 2983.4 & 6.1 & 121.4 & 97.9 & 0.0 & 69.9 & 313.2 & 187.9 & 59.8 \\
\hline 40 & 2019 & 22474.9 & 5646.9 & 6036.0 & 2556.8 & 8580.4 & 3.8 & 457.7 & \pm 50.6 & 0.0 & 64.5 & 332.9 & 184.1 & 74.6 \\
\hline 50 & 2029 & 29088.8 & 5880.5 & 6285.6 & 2661.9 & 14733.5 & 2.0 & 639.2 & 453.5 & 0.0 & 48.4 & 366.5 & 178.6 & 66.9 \\
\hline 60 & 2039 & 29969.0 & 5245.7 & 5607.1 & 2519.9 & 18208.8 & 1.6 & 748.4 & 1656.0 & 0.0 & 30.0 & 499.4 & 129.3 & 47.7 \\
\hline 70 & 2049 & 6918.0 & 1271.9 & 1359.5 & 2289.3 & 16854.9 & 2.2 & 831.0 & 10286.1 & 4598.0 & 7.8 & 864.9 & 0.0 & 34.0 \\
\hline 80 & 2059 & -699.7 & 380.7 & 406.9 & 2157.0 & 12733.7 & 1.1 & 853.9 & 9484.7 & 6705.7 & 0.0 & 1009.9 & 0.0 & 32.8 \\
\hline 90 & 2069 & -1318.8 & 0.0 & 0.0 & 2231.5 & 12177.2 & -5.9 & 850.3 & 8420.3 & 7683.7 & 0.0 & 435.5 & 0.0 & 32.4 \\
\hline
\end{tabular}


APPENDIX TABLE 3

Continued

\begin{tabular}{|c|c|c|c|c|c|c|c|c|c|c|c|c|c|c|}
\hline & & & & & & & Average m & al values of & eceipts ano & oumerts & & & & \\
\hline Coht & t that & & & & & $y$ ments & & & & & & ipts & & \\
\hline in & 989 & & $\begin{array}{l}\text { Labor } \\
\text { income }\end{array}$ & FICA & Excise & $\begin{array}{l}\text { Capital } \\
\text { income }\end{array}$ & Seignor- & Property & & & & fare & & \\
\hline Age & Year & payment & taxes & taxes & taxes & taxes & age & taxes & OASDI & $\mathrm{HI}$ & AFDC & General & UI & Stamps \\
\hline 20 & 1989 & 3819.0 & 1263.6 & 1350.7 & 1378.1 & 157.6 & 12.5 & 3.7 & 72.8 & 0.0 & 7.9 & 193.5 & 58.9 & 14.3 \\
\hline 30 & 1999 & 12146.2 & 3841.8 & 4106.5 & 1987.2 & 2768.6 & 5.7 & 112.6 & 90.8 & 0.0 & 64.9 & 290.6 & 174.4 & 55.5 \\
\hline 40 & 2009 & 20856.8 & 5240.4 & 5601.4 & 2372.7 & 7962.6 & 3.5 & 424.8 & 139.8 & 0.0 & 59.9 & 308.9 & 170.9 & 69.2 \\
\hline 50 & 2019 & 26994.5 & 5457.1 & 5833.0 & 2470.3 & 13672.7 & 1.8 & 593.2 & 420.8 & 0.0 & 44.9 & 340.1 & 165.7 & 62.1 \\
\hline 60 & 2029 & 27811.3 & 4868.0 & 5203.4 & 2338.5 & 16897.8 & 1.5 & 694.5 & .1536 .8 & 0.0 & 27.9 & 463.5 & 120.0 & 44.2 \\
\hline 70 & 2039 & 6419.9 & 1180.3 & 1261.4 & 2124.5 & 15641.4 & 2.0 & 771.2 & 9452.7 & 4267.0 & 7.2 & 802.6 & 0.0 & 31.5 \\
\hline 80 & 2049 & -649.4 & 353.3 & 377.6 & 2001.7 & 11816.9 & 1.1 & 792.5 & 8801.6 & 6222.9 & 0.0 & 937.2 & 0.0 & 30.4 \\
\hline 90 & 2059 & -1223.9 & 0.0 & 0.0 & 2070.9 & 11300.4 & -5.4 & 789.1 & 7814.1 & 7130.5 & 0.0 & 404.2 & 0.0 & 30.1 \\
\hline $\begin{array}{c}\text { Cohn } \\
\text { is } \\
\text { in }\end{array}$ & $\begin{array}{l}\text { that } \\
\text { e } 30 \\
989\end{array}$ & & $\begin{array}{l}\text { Labor } \\
\text { income }\end{array}$ & & & $\begin{array}{l}\text { Capital } \\
\text { income }\end{array}$ & & & & & & fare & & \\
\hline Age & Year & payment & taxes & taxes & taxes & taxes & age & taxes & DASDI & $\mathrm{Hl}$ & AFDC & General & U] & Stamps \\
\hline 30 & 1989 & 11271.7 & 3565.2 & 3810.9 & 1844.1 & 2569.3 & 5.3 & 104.5 & 84.3 & 0.0 & 60.2 & 269.7 & 161.9 & 51.5 \\
\hline 40 & 1999 & 19355.1 & 4863.1 & 5198.1 & 2201.9 & 7389.3 & 3.3 & 394.2 & 129.7 & 0.0 & 55.6 & 286.7 & 158.6 & 64.2 \\
\hline 50 & 2009 & 25051.0 & 5064.2 & 5413.1 & 2292.4 & 12688.3 & 1.7 & 550.5 & 390.5 & 0.0 & 41.6 & 315.6 & 153.8 & 57.6 \\
\hline 60 & 2019 & 25809.0 & 4517.6 & 4828.8 & 2170.1 & 15681.2 & 1.4 & 644.5 & 1426.1 & 0.0 & 25.9 & 430.1 & 111.4 & 41.0 \\
\hline 70 & 2029 & 5957.7 & 1095.3 & 1170.8 & 1971.5 & 14515.3 & 1.9 & 715.7 & 8772.2 & 3959.7 & 6.7 & 744.8 & 0.0 & 29.3 \\
\hline 80 & 2039 & -602.6 & 327.9 & 350.4 & 1857.6 & 10966.1 & 1.0 & 735.4 & 8168.1 & 5774.9 & 0.0 & 869.7 & 0.0 & 28.2 \\
\hline 90 & 2049 & -1135.7 & 0.0 & 0.0 & 1921.8 & 10486.9 & -5.1 & 732.3 & 7251.5 & 6617.1 & 0.0 & 375.1 & 0.0 & 27.9 \\
\hline
\end{tabular}


Cohort that
is age 40

\begin{tabular}{|c|c|c|c|c|c|c|c|c|c|c|c|c|c|c|}
\hline \multicolumn{2}{|c|}{$\begin{array}{l}\text { is age } 40 \\
\text { in } 7989\end{array}$} & \multirow{2}{*}{$\begin{array}{c}\text { Net } \\
\text { payment }\end{array}$} & \multirow{2}{*}{$\begin{array}{l}\text { Labor } \\
\text { income } \\
\text { taxes }\end{array}$} & \multirow{2}{*}{$\begin{array}{l}\text { FICA } \\
\text { taxes }\end{array}$} & \multirow{2}{*}{$\begin{array}{l}\text { Excise } \\
\text { taxes }\end{array}$} & \multirow{2}{*}{$\begin{array}{c}\text { Capital } \\
\text { income } \\
\text { taxes }\end{array}$} & \multirow{2}{*}{$\begin{array}{l}\text { Seignor- } \\
\text { age }\end{array}$} & \multirow{2}{*}{$\begin{array}{l}\text { Property } \\
\text { taxes }\end{array}$} & \multirow[b]{2}{*}{ OASDJ } & \multirow[b]{2}{*}{$\mathrm{H} 3$} & \multicolumn{2}{|c|}{ Welfare } & \multirow[b]{2}{*}{$\mathrm{Ut}$} & \multirow{2}{*}{$\begin{array}{l}\text { Food } \\
\text { Stamps }\end{array}$} \\
\hline Age & Year & & & & & & & & & & AFDC & General & & \\
\hline 40 & 1989 & 17961.6 & 4513.0 & 4823.9 & 2043.4 & 6857.3 & 3.1 & 365.8 & 120.4 & 0.0 & 51.6 & 266.0 & 147.1 & 59.6 \\
\hline 50 & 1999 & 23247.4 & 4699.6 & 5023.4 & 2127.4 & 11774.8 & 1.6 & 510.8 & 362.4 & 0.0 & 38.6 & 292,9 & 142.7 & 53.5 \\
\hline 60 & 2009 & 23950.8 & 4192.3 & 4481.1 & 2013.9 & 14552.2 & 1.3 & 598.1 & 1323.5 & 0.0 & 24.0 & 399.1 & 103.4 & 38.1 \\
\hline 70 & 2019 & 5528.8 & 1016.5 & 1086.5 & 1829.6 & 13470.2 & 1.7 & 664.2 & 8140.6 & 3674.7 & 6.2 & 691.2 & 0.0 & 27.2 \\
\hline 80 & 2029 & -559.2 & 304.3 & 325.2 & 1723.9 & 10176.6 & 0.9 & 682.5 & 7580.0 & 5359.1 & 0.0 & 807.1 & 0.0 & 26.2 \\
\hline 90 & 2039 & -1054.0 & 0.0 & 0.0 & 1783.4 & 9731.8 & -4.7 & 679.6 & 6729.4 & 6140.7 & 0.0 & 348.1 & 0.0 & 25.9 \\
\hline
\end{tabular}

Cohort that
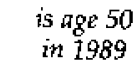

\begin{tabular}{|c|c|c|c|c|c|c|c|c|c|c|c|c|}
\hline \multirow{2}{*}{$\begin{array}{c}\text { Net } \\
\text { payment }\end{array}$} & \multirow{2}{*}{$\begin{array}{c}\text { Labor } \\
\text { jncome } \\
\text { taxes }\end{array}$} & \multirow{2}{*}{$\begin{array}{l}\text { FICA } \\
\text { taxes }\end{array}$} & \multirow{2}{*}{$\begin{array}{l}\text { Excise } \\
\text { taxes }\end{array}$} & \multirow{2}{*}{$\begin{array}{c}\text { Capital } \\
\text { income } \\
\text { taxes }\end{array}$} & \multirow{2}{*}{$\begin{array}{l}\text { Seignor- } \\
\text { age }\end{array}$} & \multirow{2}{*}{$\begin{array}{l}\text { Property } \\
\text { taxes }\end{array}$} & \multirow[b]{2}{*}{ OASDI } & \multirow[b]{2}{*}{$\mathrm{HI}$} & \multicolumn{2}{|c|}{ Welfare } & \multirow[b]{2}{*}{ UI } & \multirow{2}{*}{$\begin{array}{c}\text { Food } \\
\text { Stamps }\end{array}$} \\
\hline & & & & & & & & & AFDC & General & & \\
\hline 21573.6 & 4361.2 & 4661.7 & 1974.2 & 10927.1 & 1.5 & 474.0 & 336.3 & 0.0 & 33.9 & 2718 & 132.4 & 49.6 \\
\hline 22226.5 & 3890.5 & 4158.5 & 1868.9 & 13504.5 & 1.2 & 555.1 & 1228.2 & 0.0 & 22.3 & 370.4 & 95.9 & 35.3 \\
\hline 4242.0 & 943.3 & 1008.3 & 1697.9 & 12500.4 & 1.6 & 6163 & 8443.3 & 3420.7 & 5.8 & 641.5 & 0.0 & 25.2 \\
\hline-1346.5 & 282.3 & 301.8 & 1599.7 & 9443.9 & 0.8 & 633.3 & 7861.9 & 4973.3 & 0.0 & 749.0 & 0.0 & 24.3 \\
\hline-1712.8 & 0.0 & 0.0 & 1655.0 & 9031.2 & -4.4 & 630.6 & 6979.6 & 5698.6 & 0.0 & 323.0 & 0.0 & 24.0 \\
\hline \multirow{2}{*}{$\begin{array}{c}\text { Net } \\
\text { payment }\end{array}$} & \multirow{2}{*}{$\begin{array}{l}\text { Labor } \\
\text { income } \\
\text { taxes }\end{array}$} & \multirow{2}{*}{$\begin{array}{l}\text { FICA } \\
\text { taxes }\end{array}$} & \multirow{2}{*}{$\begin{array}{c}\text { Excise } \\
\text { taxes }\end{array}$} & \multirow{2}{*}{$\begin{array}{c}\text { Capital } \\
\text { income } \\
\text { taxes }\end{array}$} & \multirow{2}{*}{$\begin{array}{c}\text { Seignor- } \\
\text { age }\end{array}$} & \multirow{2}{*}{$\begin{array}{c}\text { Property } \\
\text { taxes }\end{array}$} & \multirow[b]{2}{*}{ OASDI } & \multirow[b]{2}{*}{$\mathrm{HI}$} & \multicolumn{2}{|c|}{ Welfare } & \multirow[b]{2}{*}{ UI } & \multirow{2}{*}{$\begin{array}{l}\text { Food } \\
\text { Stamps }\end{array}$} \\
\hline & & & & & & & & & $A F D C$ & General & & \\
\hline 20626.2 & 3610.4 & 3859.1 & 1734.3 & 12532.2 & 1.1 & 515.1 & 1139.8 & 0.0 & 20.7 & 343.7 & 89.0 & 32.8 \\
\hline 3524.2 & 875.4 & 935.7 & 1575.6 & 11600.4 & 1.5 & 572.0 & 8247.8 & 3164.6 & 5.4 & 595.3 & 0.0 & 23.4 \\
\hline-1633.6 & 262.0 & 280.1 & 1484.6 & 8764.0 & 0.8 & 587.7 & 7679.8 & 4615.2 & 0.0 & 695.1 & 0.0 & 22.6 \\
\hline-1930.4 & 0.0 & 0.0 & 1535.8 & 8381.0 & -40 & 585.2 & 6818.0 & 5288.3 & 0.0 & 299.7 & 0.0 & 22.3 \\
\hline
\end{tabular}




\section{APPENDIX TABLE 3}

Continued

\begin{tabular}{|c|c|c|c|c|c|c|c|c|c|c|c|c|c|c|}
\hline \multirow{3}{*}{\multicolumn{2}{|c|}{$\begin{array}{c}\text { Cohort that } \\
\text { is age } 70 \\
\text { in } 1989 \\
\end{array}$}} & \multirow{4}{*}{$\begin{array}{c}\text { Net } \\
\text { payment }\end{array}$} & \multicolumn{12}{|c|}{ Average annual vaines of recetpts and payments } \\
\hline & & & \multicolumn{6}{|c|}{ Payments } & \multicolumn{6}{|c|}{ Receipis } \\
\hline & & & \multirow{2}{*}{$\begin{array}{l}\text { Labor } \\
\text { income } \\
\text { taxes }\end{array}$} & \multirow{2}{*}{$\begin{array}{l}\text { FICA } \\
\text { taxes }\end{array}$} & \multirow{2}{*}{$\begin{array}{l}\text { Excise } \\
\text { taxes }\end{array}$} & \multirow{2}{*}{$\begin{array}{c}\text { Capital } \\
\text { income } \\
\text { taxes }\end{array}$} & \multirow{2}{*}{$\begin{array}{l}\text { Seignor- } \\
\text { age }\end{array}$} & \multirow{2}{*}{$\begin{array}{l}\text { Property } \\
\text { taxes }\end{array}$} & \multirow[b]{2}{*}{ OASDI } & \multirow[b]{2}{*}{$\mathrm{HI}$} & \multicolumn{2}{|c|}{ Wetfare } & \multirow[b]{2}{*}{ UI } & \multirow{2}{*}{$\begin{array}{l}\text { Food } \\
\text { Stamps }\end{array}$} \\
\hline Age & Year & & & & & & & & & & AFDC & General & & \\
\hline 70 & 1989 & 3270.4 & 812,3 & 868.3 & 1462.2 & 10765.2 & 1.4 & 530.8 & 7654.0 & 2936.7 & 5,0 & 552.4 & 0.0 & 21.7 \\
\hline 80 & \pm 999 & -1516.0 & 243.2 & 259.9 & 1377.7 & 8133.0 & 0.7 & 545.4 & 7126.9 & 4283.0 & 0.0 & 645.0 & 0.0 & 20.9 \\
\hline 90 & 2009 & -1791.4 & 0.0 & 0.0 & 1425.3 & 7777.6 & -3.7 & 543.1 & 6327.1 & 4907.6 & 0.0 & 278.2 & 0.0 & 20.7 \\
\hline \multicolumn{2}{|c|}{$\begin{array}{c}\text { Cohort that } \\
\text { is age } 80 \\
\text { in } 1989 \\
\end{array}$} & \multirow{2}{*}{$\begin{array}{c}\text { Net } \\
\text { payment }\end{array}$} & \multirow{2}{*}{$\begin{array}{l}\text { Labor } \\
\text { income } \\
\text { taxes }\end{array}$} & \multirow{2}{*}{$\begin{array}{l}\text { FICA } \\
\text { taxes }\end{array}$} & \multirow{2}{*}{$\begin{array}{l}\text { Excise } \\
\text { taxes }\end{array}$} & \multirow{2}{*}{$\begin{array}{c}\text { Capital } \\
\text { incorie } \\
\text { taxes }\end{array}$} & \multirow{2}{*}{$\begin{array}{c}\text { 5eignor- } \\
\text { age }\end{array}$} & \multirow{2}{*}{$\begin{array}{l}\text { Property } \\
\text { taxes }\end{array}$} & \multirow[b]{2}{*}{ OASDI } & \multirow[b]{2}{*}{$\mathrm{HI}$} & \multicolumn{2}{|c|}{ Welfare } & \multirow[b]{2}{*}{ U1 } & \multirow{2}{*}{$\begin{array}{l}\text { Food } \\
\text { Stamps }\end{array}$} \\
\hline Age & Year & & & & & & & & & & AFDC & General & & \\
\hline 80 & 1989 & -1406.8 & 225.6 & 241.2 & 1278.5 & 7547.4 & 0.7 & 506.1 & 6613.8 & 3974.6 & 0.0 & 598.6 & 0.0 & 19.4 \\
\hline 90 & 1999 & -1662.4 & 0.0 & 0.0 & 1322.7 & 7217.6 & -3.5 & 504.0 & 5871.6 & 4554.2 & 0.0 & 258.1 & 0.0 & 19.2 \\
\hline \multicolumn{2}{|c|}{$\begin{array}{c}\text { Cohtort that } \\
\text { is age } 90 \\
\text { in } 1989 \\
\end{array}$} & \multirow{2}{*}{$\begin{array}{c}\text { Net } \\
\text { payment }\end{array}$} & \multirow{2}{*}{$\begin{array}{l}\text { Labor } \\
\text { income } \\
\text { taxes }\end{array}$} & \multirow{2}{*}{$\begin{array}{l}\text { FICA } \\
\text { taxes }\end{array}$} & \multirow{2}{*}{$\begin{array}{l}\text { Excise } \\
\text { taxes }\end{array}$} & \multirow{2}{*}{$\begin{array}{c}\text { Capital } \\
\text { income } \\
\text { taxes }\end{array}$} & Seignor- & Property & & & & fare & & Food \\
\hline Age & Year & & & & & & age & taxes & OASDI & $\mathrm{HI}$ & $\mathrm{AFDC}$ & General & UI & Stamps \\
\hline 90 & 1989 & -1542.7 & 0.0 & 0.0 & 1227.4 & 6697.9 & -3.2 & 467.7 & 5448.9 & 4226.3 & 0.0 & 239.5 & 0.0 & 17.8 \\
\hline
\end{tabular}


APPENDIX TABLE 4

The Components of Female Generational Accounts $(r=.06, g=.0075)$

\begin{tabular}{|c|c|c|c|c|c|c|c|c|c|c|c|c|c|c|}
\hline \multirow{3}{*}{\multicolumn{2}{|c|}{$\begin{array}{c}\text { Cohont that } \\
\text { is age } \\
0 \text { in } 1989\end{array}$}} & \multirow{4}{*}{$\begin{array}{c}\text { Net } \\
\text { payment }\end{array}$} & \multicolumn{12}{|c|}{ Average annual values of receipts and payments } \\
\hline & & & \multicolumn{6}{|c|}{ Payments } & \multicolumn{6}{|c|}{ Receipts } \\
\hline & & & \multirow{2}{*}{$\begin{array}{l}\text { Labor } \\
\text { income } \\
\text { taxes }\end{array}$} & \multirow{2}{*}{$\begin{array}{l}\text { FlCA } \\
\text { taxes }\end{array}$} & \multirow{2}{*}{$\begin{array}{c}\text { Excise } \\
\text { taxes }\end{array}$} & \multirow{2}{*}{$\begin{array}{c}\text { Capital } \\
\text { income } \\
\text { taxes }\end{array}$} & \multirow{2}{*}{$\begin{array}{c}\text { Seignor- } \\
\text { age }\end{array}$} & \multirow{2}{*}{$\begin{array}{c}\text { Property } \\
\text { taxes }\end{array}$} & \multirow[b]{2}{*}{ OASD] } & \multirow[b]{2}{*}{ HI } & \multicolumn{2}{|c|}{ Welfare } & \multirow[b]{2}{*}{ UI } & \multirow{2}{*}{$\begin{array}{c}\text { Food } \\
\text { Stamps }\end{array}$} \\
\hline Age & Year & & & & & & & & & & AFDC & General & & \\
\hline 0 & 1989 & 26.2 & 0.0 & 0.0 & 501.4 & 0.0 & 0.0 & 0.0 & 21.4 & 0.0 & 0.0 & 453.8 & 0.0 & 0.0 \\
\hline 10 & 1999 & 319.9 & 0.0 & 0.0 & 655.0 & 0.0 & 0.0 & 0.0 & 81.5 & 0.0 & 0.0 & 253.6 & 0.0 & 0.0 \\
\hline 20 & 2009 & 2527.8 & 1074.3 & 1148.3 & 1358.1 & 0.0 & 5.2 & 30.3 & 80.0 & 0.0 & 389.0 & 390.4 & 42.7 & 186.3 \\
\hline 30 & 2019 & 6509.9 & 2512.9 & 2686.0 & 2123.5 & 598.3 & 3.3 & 250.4 & 258.3 & 0.0 & 445,4 & 599.1 & 87.3 & 274.4 \\
\hline 40 & 2029 & 10579.5 & 2981.7 & 3187.1 & 2632.1 & 2985.7 & 0.8 & 479.7 & 490.2 & 0.0 & 303.5 & 598.0 & 84.3 & 211.6 \\
\hline 50 & 2039 & 14430.3 & 3022.8 & 3231.1 & 2744.8 & 6230.2 & 0.2 & 703.1 & 574.5 & 0.0 & 152.1 & 595.6 & 72.2 & 107.5 \\
\hline 60 & 2049 & 15001.3 & 2374.1 & 2537.7 & 2500.1 & 8921.5 & 2.3 & 882.6 & 1449.1 & 0.0 & 32.8 & 622.8 & 50.8 & 61.4 \\
\hline 70 & 2059 & 885.6 & 822.3 & 879.0 & 20905 & 9683.5 & 5.9 & 1021.5 & 7596.0 & 4954.7 & 0.0 & 1009.0 & 6.2 & 51.1 \\
\hline 80 & 2069 & -5558.9 & 57.4 & 61.4 & 1811.8 & 7978.8 & 6.6 & 1202.0 & 8281.0 & 7226.0 & 0.0 & 1114.8 & 0.0 & 55.1 \\
\hline 90 & 2079 & -13169.7 & 0.0 & 0.0 & 1974.6 & 873.2 & -2.6 & 1429.6 & 7900.8 & 8279.8 & 0.0 & 1204.6 & 0.0 & 59.4 \\
\hline \multicolumn{2}{|c|}{$\begin{array}{c}\text { Cohort that } \\
\text { is age } 10 \\
\text { in } 1989\end{array}$} & \multirow{2}{*}{$\begin{array}{c}\text { Net } \\
\text { payment }\end{array}$} & \multirow{2}{*}{$\begin{array}{c}\text { Labor } \\
\text { income } \\
\text { taxes }\end{array}$} & \multirow{2}{*}{$\begin{array}{l}\text { FHCA } \\
\text { taxes }\end{array}$} & \multirow{2}{*}{$\begin{array}{c}\text { Excise } \\
\text { taxes }\end{array}$} & \multirow{2}{*}{$\begin{array}{c}\text { Capital } \\
\text { income } \\
\text { taxes }\end{array}$} & \multirow{2}{*}{$\begin{array}{c}\text { Seignor- } \\
\text { age }\end{array}$} & \multirow{2}{*}{$\begin{array}{l}\text { Property } \\
\text { taxes }\end{array}$} & \multirow[b]{2}{*}{ OASDI } & \multirow[b]{2}{*}{$\mathrm{HI}$} & & \multirow[b]{2}{*}{ UI } & \multirow{2}{*}{$\begin{array}{l}\text { Food } \\
\text { Stamps }\end{array}$} \\
\hline Age & Year & & & & & & & & & & AFDC & General & & \\
\hline 10 & 1989 & 296.9 & 0.0 & 0.0 & 607.8 & 0.0 & 0.0 & 0.0 & 75.6 & 0.0 & 0.0 & 235.3 & 0.0 & 0.0 \\
\hline 20 & 1999 & 2345.8 & 996.9 & 1865.6 & 1260.3 & 0.0 & 4.8 & 28.2 & 74.2 & 0.0 & 361.0 & 362.3 & 39.6 & 172.9 \\
\hline 30 & 2009 & 6041.2 & 2332.0 & 2492.6 & 1970.6 & 555.2 & 3.0 & 232.4 & 239.7 & 0.0 & 413.4 & 556.0 & 810 & 254.6 \\
\hline 40 & 2019 & 9817.8 & 2767.0 & 2957.6 & 2442.6 & 2770.8 & 0.7 & 445.2 & 454.9 & 0.0 & 281.7 & 554.9 & 78.2 & 196.3 \\
\hline 50 & 2029 & 13391.4 & 2805.2 & 2998.5 & 2547.2 & 5781.6 & 0.2 & 652.5 & 533.2 & 0.0 & 141.2 & 552.7 & 67.0 & 99.8 \\
\hline 60 & 2039 & 13921.3 & 2203.2 & 2355.0 & 2320.1 & 8279.2 & 2.2 & 819.0 & 1344.8 & 0.0 & 30.4 & 578.0 & 47.1 & 57.0 \\
\hline 70 & 2049 & 821.9 & 763.1 & 815.7 & 1940.0 & 8986.3 & 5.5 & 948.0 & 7049.1 & 4598.0 & 0.0 & 936.4 & 5.8 & 47.5 \\
\hline 80 & 2059 & -5158.7 & 53.3 & 57.0 & 1681.4 & 7404.4 & 6.1 & 1115.4 & 7684.8 & 6705.7 & 0.0 & 1034.5 & 0.0 & 51.1 \\
\hline 90 & 2069 & -12221.5 & 0.0 & 0.0 & 1832.4 & 810.3 & -2.4 & 1326.7 & 7331.9 & 7683.7 & 0.0 & 1117.8 & 0.0 & 55.1 \\
\hline
\end{tabular}




\section{APPENDIX TABLE}

Continued

\begin{tabular}{|c|c|c|c|c|c|c|c|c|c|c|c|c|c|c|}
\hline \multirow{3}{*}{\multicolumn{2}{|c|}{$\begin{array}{l}\text { Cohort that } \\
\text { is age } 20 \\
\text { in } 1989\end{array}$}} & \multirow{4}{*}{$\begin{array}{c}\text { Net } \\
\text { payment }\end{array}$} & \multicolumn{12}{|c|}{ Average anmual palues of receipts and payments } \\
\hline & & & \multicolumn{6}{|c|}{ Payments } & \multicolumn{6}{|c|}{ Receipfs } \\
\hline & & & \multirow{2}{*}{$\begin{array}{l}\text { Labor } \\
\text { jncome } \\
\text { taxes }\end{array}$} & \multirow{2}{*}{$\begin{array}{l}\text { FICA } \\
\text { taxes }\end{array}$} & \multirow{2}{*}{$\begin{array}{l}\text { Excise } \\
\text { taxes }\end{array}$} & \multirow{2}{*}{$\begin{array}{l}\text { Capital } \\
\text { income } \\
\text { taxes }\end{array}$} & \multirow{2}{*}{$\begin{array}{l}\text { Seignor- } \\
\text { age }\end{array}$} & \multirow{2}{*}{$\begin{array}{c}\text { Property } \\
\text { taxes }\end{array}$} & \multirow[b]{2}{*}{ OASDI } & \multirow[b]{2}{*}{$\mathrm{H}]$} & \multicolumn{2}{|c|}{ Welfare } & \multirow[b]{2}{*}{$\mathrm{UI}$} & \multirow{2}{*}{$\begin{array}{c}\text { Food } \\
\text { Stamps }\end{array}$} \\
\hline Age & Year & & & & & & & & & & AFDC & Genetal & & \\
\hline 20 & 1989 & 2176.9 & 925.2 & 988.9 & 1169.6 & 0.0 & 4.5 & 26.1 & 68.9 & 0.0 & 335.0 & 336.2 & 36.8 & 160.5 \\
\hline 30 & 1999 & 5606.2 & 2164.1 & 2313.2 & 1828.7 & 515,3 & 2.8 & 215.7 & 222.5 & 0.0 & 383.6 & 515.9 & 75.2 & 236.3 \\
\hline 40 & 2009 & 9120.9 & 2567.8 & 2744.7 & 2266.7 & 2577.3 & 0.7 & 413.1 & 422.2 & 0.0 & 261.4 & 515.0 & 72.6 & 182.2 \\
\hline 50 & 2019 & 12427.2 & 2603.2 & 2782.6 & 2363.8 & 5365.4 & 0.1 & 605.5 & 494.8 & 0.0 & 131.0 & 512.9 & 62.1 & 92.6 \\
\hline 60 & 2029 & 12919.0 & 2044.6 & 2185.4 & 2153.0 & 7683.1 & 2.0 & 760.1 & 1248.0 & 0.0 & 28.2 & 536.4 & 43.7 & 52.9 \\
\hline 70 & 2039 & 762.7 & 708.2 & 757.0 & 18003 & 8339.3 & 5.1 & 879.7 & 6541.6 & 4267.0 & 0.0 & 868.9 & 5.3 & 44.0 \\
\hline 80 & 2049 & -4787.3 & 49.5 & 52.9 & 1560.3 & 6871.3 & 5.6 & $1035 . \mathrm{I}$ & 7131.5 & 6222.9 & 0.0 & 960.0 & 0.0 & 47.5 \\
\hline 90 & 2059 & -11341.6 & 0.0 & 0.0 & 1700.5 & 752.0 & -2.3 & 1231.2 & 6804.0 & 7130.5 & 0.0 & 1037.4 & 0.0 & 51.1 \\
\hline \multicolumn{2}{|c|}{$\begin{array}{c}\text { Cohort that } \\
\text { is age } 30 \\
\text { in } 1989\end{array}$} & \multirow{2}{*}{$\begin{array}{c}\text { Net } \\
\text { payment }\end{array}$} & \multirow{2}{*}{$\begin{array}{l}\text { Labor } \\
\text { income } \\
\text { taxes }\end{array}$} & \multirow{2}{*}{$\begin{array}{l}\text { FICA } \\
\text { taxes }\end{array}$} & \multirow{2}{*}{$\begin{array}{l}\text { Excise } \\
\text { taxes }\end{array}$} & \multirow{2}{*}{$\begin{array}{l}\text { Capital } \\
\text { income } \\
\text { taxes }\end{array}$} & \multirow{2}{*}{$\begin{array}{l}\text { Seignor- } \\
\text { age }\end{array}$} & \multirow{2}{*}{$\begin{array}{l}\text { Property } \\
\text { taxes }\end{array}$} & \multirow[b]{2}{*}{ OASDI } & \multirow[b]{2}{*}{$\mathrm{HI}$} & \multicolumn{2}{|c|}{ Welfare } & \multirow[b]{2}{*}{ UI } & \multirow{2}{*}{$\begin{array}{l}\text { Food } \\
\text { Stamps }\end{array}$} \\
\hline Age & $\overline{\text { Year }}$ & & & & & & & & & & $A F D C$ & General & & \\
\hline 30 & 1989 & 5202.6 & 2008.3 & 2146.6 & 1697.1 & 478.2 & 2.6 & 200.2 & 206.5 & 0.0 & 356.0 & 478.8 & 69.7 & 219.3 \\
\hline 40 & 1999 & 8455.0 & 2382.9 & 2547.1 & 2103.5 & 2386.2 & 0.6 & 383.4 & 391.0 & 0.0 & 242.6 & 477.9 & 67.4 & 169.1 \\
\hline 50 & 2009 & 11532.5 & 2415.8 & 2582.2 & 2193.6 & 4979.1 & 0.1 & 561.9 & 459.2 & 0.0 & 121.6 & 476.0 & 57.7 & 85.9 \\
\hline 60 & 2019 & 11988.9 & 1897.4 & 2028.1 & 1998.0 & 7129.9 & 1.9 & 705.3 & 1158.1 & 0.0 & 26.2 & 497.7 & 40.6 & 49.1 \\
\hline 70 & 2029 & 707.8 & 657.2 & 702.5 & 1670.7 & 7738.9 & 4.8 & 816.4 & 6070.6 & 3959.7 & 0.0 & 806.4 & 5.0 & 40.9 \\
\hline 80 & 2039 & -4442.6 & 45.9 & 49.1 & 1448.0 & 6376.6 & 5.2 & 960.6 & 6618.0 & 5774.9 & 0.0 & 890.9 & 0.0 & 44.0 \\
\hline 90 & 2049 & -10525.0 & 0.0 & 0.0 & 1578.1 & 697.9 & -2.1 & 1142.5 & 6314.2 & 6617.1 & 0.0 & 962.7 & 0.0 & 47.5 \\
\hline
\end{tabular}




\begin{tabular}{|c|c|c|c|c|c|c|c|c|c|c|c|c|c|c|}
\hline \multicolumn{2}{|c|}{$\begin{array}{c}\text { Cohort that } \\
\text { is age } 40 \\
\text { in } 1989\end{array}$} & \multirow{2}{*}{$\begin{array}{c}\text { Net } \\
\text { payment }\end{array}$} & \multirow{2}{*}{$\begin{array}{l}\text { Labor } \\
\text { income } \\
\text { taxes }\end{array}$} & \multirow{2}{*}{$\begin{array}{l}\text { FICA } \\
\text { taxes }\end{array}$} & \multirow{2}{*}{$\begin{array}{c}\text { Excise } \\
\text { taxes }\end{array}$} & \multirow{2}{*}{$\begin{array}{c}\text { Capital } \\
\text { income } \\
\text { taxes }\end{array}$} & \multirow{2}{*}{$\begin{array}{l}\text { Seignor- } \\
\text { age }\end{array}$} & \multirow{2}{*}{$\begin{array}{c}\text { Property } \\
\text { taxes }\end{array}$} & \multirow[b]{2}{*}{ OASD] } & \multirow[b]{2}{*}{$\mathrm{HI}$} & \multicolumn{2}{|c|}{ Welfare } & \multirow[b]{2}{*}{ UI } & \multirow{2}{*}{$\begin{array}{l}\text { Food } \\
\text { Stamps }\end{array}$} \\
\hline Age & Year & & & & & & & & & & AFDC & General & & \\
\hline 40 & 1989 & 7846.2 & 2211.4 & 2363.7 & 1952.1 & 2214.4 & 0.6 & 355.8 & 363.6 & 0.0 & 225.1 & 443.5 & 62.5 & 156.9 \\
\hline 50 & 1999 & 10702.2 & 2241.9 & 2396.3 & 2035.7 & 4620.6 & 0.1 & 521.5 & 426.1 & 0.0 & 112.8 & 441.7 & 53.5 & 79.7 \\
\hline 60 & 2009 & 11125.7 & 1760.8 & 1882.1 & 1854.2 & 6616.6 & 1.7 & 654.6 & 1074.7 & 0.0 & 24.3 & 461.9 & 37.7 & 45.5 \\
\hline 70 & 2019 & 656.8 & 609.9 & 651.9 & 1550.4 & 7181.8 & 4.4 & 757.6 & 5633.6 & 3674.7 & 0.0 & 748.3 & 4.6 & 37.9 \\
\hline 80 & 2029 & -4122.7 & 42.6 & 45.5 & 1343.7 & 5917.5 & 4.9 & 891.4 & 6141.6 & 5359.1 & 0.0 & 826.8 & 0.0 & 40.9 \\
\hline 90 & 2039 & -9767.3 & 0.0 & 0.0 & 1464.4 & 647.6 & -1.9 & 1060.3 & 5859.6 & 6140.7 & 0.0 & 893.4 & 0.0 & 44.0 \\
\hline \multirow{2}{*}{\multicolumn{2}{|c|}{$\begin{array}{c}\text { Cohort that } \\
\text { is age } 50 \\
\text { in } 1989 \\
\end{array}$}} & \multirow{3}{*}{$\begin{array}{c}\text { Net } \\
\text { payment }\end{array}$} & \multirow{3}{*}{$\begin{array}{l}\text { Labor } \\
\text { income } \\
\text { taxes }\end{array}$} & \multirow{3}{*}{$\begin{array}{l}\text { FICA } \\
\text { taxes }\end{array}$} & \multirow{3}{*}{$\begin{array}{l}\text { Excise } \\
\text { taxes }\end{array}$} & \multirow{3}{*}{$\begin{array}{c}\text { Capital } \\
\text { income } \\
\text { taxes }\end{array}$} & \multirow{3}{*}{$\begin{array}{l}\text { Seignor- } \\
\text { age }\end{array}$} & \multirow{3}{*}{$\begin{array}{c}\text { Property } \\
\text { taxes }\end{array}$} & \multirow[b]{3}{*}{ OASD] } & \multirow[b]{3}{*}{ HI } & \multirow{2}{*}{\multicolumn{2}{|c|}{ Welfare }} & \multirow[b]{3}{*}{ UI } & \multirow{3}{*}{$\begin{array}{c}\text { Food } \\
\text { 5tamps }\end{array}$} \\
\hline & & & & & & & & & & & & & & \\
\hline Age & Year & & & & & & & & & & AFDC & General & & \\
\hline 50 & 1989 & 9931.7 & 2080.5 & 2223.8 & 1889.1 & 4287.9 & 0.1 & 483.9 & 395.4 & 0.0 & 104.7 & 409.9 & 49.7 & 74.0 \\
\hline 60 & 1999 & 10324.7 & 1634.0 & 1746.6 & 1720.7 & 6140.2 & 1.6 & 607.4 & 997.4 & 0.0 & 22.6 & 428.7 & 35.0 & 42.3 \\
\hline 70 & 2009 & -5.5 & 566.0 & 6050 & 1438.8 & 6664.7 & 4.1 & 703.1 & 5843.0 & 3410.1 & 0.0 & 694.5 & 4.3 & 35.2 \\
\hline 80 & 2019 & -4496.4 & 39.5 & 42.3 & 1247.0 & 5491.4 & 4.5 & 827.3 & 6369.9 & 4973.3 & 0.0 & 767.3 & 0.0 & 37.9 \\
\hline 90 & 2029 & -9703.8 & 0.0 & 0.0 & 1359.0 & 601.0 & -1.8 & 983.9 & 6077.4 & 5698.6 & 0.0 & 829.0 & 0.0 & 40.9 \\
\hline \multicolumn{2}{|c|}{$\begin{array}{c}\text { Cohori that } \\
\text { is age } 60 \\
\text { in } 1989 \\
\end{array}$} & \multirow{2}{*}{$\begin{array}{c}\text { Net } \\
\text { payment }\end{array}$} & \multirow{2}{*}{$\begin{array}{c}\text { Labor } \\
\text { income } \\
\text { taxes }\end{array}$} & \multirow{2}{*}{$\begin{array}{l}\text { FICA } \\
\text { taxes }\end{array}$} & \multirow{2}{*}{$\begin{array}{c}\text { Excise } \\
\text { taxes }\end{array}$} & Capital & & & & & & fare & & \\
\hline Age & Year & & & & & taxes & age & taxes & OASDI & HI & AFDC & General & UI & Stamps \\
\hline 60 & 1989 & 9581.3 & 1516.4 & 1620.8 & 1596.8 & 5698.2 & 1.5 & 563.7 & 925.6 & 0.0 & 20.9 & 397.8 & 32.4 & 39.2 \\
\hline 70 & 1999 & -290.5 & 525.2 & 561.4 & 1335.2 & 6184.9 & 3.8 & 652.4 & 5707.7 & 3164.6 & 0.0 & 644.5 & 4.0 & 32.7 \\
\hline 80 & 2009 & -4483.8 & 36.7 & 39.2 & 1157.2 & 5096.1 & 4.2 & 767.7 & 6222.4 & 4615.2 & 0.0 & 712.0 & 0.0 & 35.2 \\
\hline 90 & 2019 & -9302.0 & 0.0 & 0.0 & 1261.2 & 557.7 & -1.7 & 913.1 & 5936.7 & 5288.3 & 0.0 & 769.4 & 0.0 & 37.9 \\
\hline
\end{tabular}


APPENDIX TABLE 4

Continued

\begin{tabular}{|c|c|c|c|c|c|c|c|c|c|c|c|c|c|c|}
\hline \multirow{3}{*}{\multicolumn{2}{|c|}{$\begin{array}{c}\text { Cohort that } \\
\text { is age } 70 \\
\text { in } 1989\end{array}$}} & \multirow{4}{*}{$\begin{array}{c}\text { Net } \\
\text { payment }\end{array}$} & \multicolumn{12}{|c|}{ Average ammual balues of receipts and payments } \\
\hline & & & \multicolumn{6}{|c|}{ Payments } & \multicolumn{6}{|c|}{ Receipts } \\
\hline & & & \multirow{2}{*}{$\begin{array}{c}\text { Labor } \\
\text { income } \\
\text { taxes }\end{array}$} & \multirow{2}{*}{$\begin{array}{l}\text { FICA } \\
\text { taxes }\end{array}$} & \multirow{2}{*}{$\begin{array}{l}\text { Excise } \\
\text { taxes }\end{array}$} & \multirow{2}{*}{$\begin{array}{c}\text { Capital } \\
\text { income } \\
\text { taxes }\end{array}$} & \multirow{2}{*}{$\begin{array}{l}\text { Seignor } \\
\text { age }\end{array}$} & \multirow{2}{*}{$\begin{array}{l}\text { Property } \\
\text { taxes }\end{array}$} & \multirow[b]{2}{*}{ OASDI } & \multirow[b]{2}{*}{$\mathrm{HI}$} & \multicolumn{2}{|c|}{ Welfare } & \multirow[b]{2}{*}{$\mathrm{U} 1$} & \multirow{2}{*}{$\begin{array}{l}\text { Food } \\
\text { Stamps }\end{array}$} \\
\hline Age & Year & & & & & & & & & & AFDC & General & & \\
\hline 70 & 1989 & -269.6 & 487.4 & 521,0 & 1239.1 & 5739.6 & 3.5 & 605.5 & 5296.8 & 2936.7 & 0.0 & 598.1 & 3.7 & 30.3 \\
\hline 80 & 1999 & -4161.0 & 34.0 & 36.4 & 1073.9 & 4729.2 & 3.9 & 712.4 & 5774.4 & 4283.0 & 0.0 & 660.8 & 0.0 & 32.7 \\
\hline 90 & 2009 & -8632.3 & 0.0 & 0.0 & 1170.4 & 517.6 & -1.6 & 847.4 & 5509.3 & 4907.6 & 0.0 & 714.0 & 0.0 & 35.2 \\
\hline \multicolumn{2}{|c|}{$\begin{array}{c}\text { Cohort that } \\
\text { is age } 80 \\
\text { in } 1989\end{array}$} & \multirow{2}{*}{$\begin{array}{c}\text { Net } \\
\text { payment }\end{array}$} & \multirow{2}{*}{$\begin{array}{l}\text { Labor } \\
\text { income } \\
\text { taxes }\end{array}$} & \multirow{2}{*}{$\begin{array}{l}\text { FICA } \\
\text { taxes }\end{array}$} & \multirow{2}{*}{$\begin{array}{l}\text { Excise } \\
\text { taxes }\end{array}$} & \multirow{2}{*}{$\begin{array}{c}\text { Capital } \\
\text { income } \\
\text { taxes }\end{array}$} & \multirow{2}{*}{$\begin{array}{l}\text { Seignor- } \\
\text { age }\end{array}$} & \multirow{2}{*}{$\begin{array}{l}\text { Property } \\
\text { taxes }\end{array}$} & \multirow[b]{2}{*}{ OASDI } & \multirow[b]{2}{*}{ Hil } & \multicolumn{2}{|c|}{ Welfare } & \multirow[b]{2}{*}{$\mathrm{UI}$} & \multirow{2}{*}{$\begin{array}{l}\text { Food } \\
\text { Stamps }\end{array}$} \\
\hline Age & Year & & & & & & & & & & $A F D C$ & General & & \\
\hline 80 & 1989 & -3861.4 & 31.6 & 33.8 & 996.6 & 4388.7 & 3.6 & 661.1 & 5358.7 & 3974.6 & 0.0 & 613.2 & 0.0 & 30.3 \\
\hline 90 & 1999 & -8010.8 & 0.0 & 0.0 & 1086.1 & 480.3 & -1.4 & 786.4 & 5112.6 & 4554.2 & 0.0 & 662.6 & 0.0 & 32.7 \\
\hline \multicolumn{2}{|c|}{$\begin{array}{c}\text { Cohore that } \\
\text { is age } 90 \\
\text { in } 1989\end{array}$} & \multirow{2}{*}{$\begin{array}{c}\text { Net } \\
\text { payment }\end{array}$} & \multirow{2}{*}{$\begin{array}{l}\text { Labor } \\
\text { jncome } \\
\text { taxes }\end{array}$} & \multirow{2}{*}{$\begin{array}{l}\text { FICA } \\
\text { taxes }\end{array}$} & \multirow{2}{*}{$\begin{array}{l}\text { Excise } \\
\text { taxes }\end{array}$} & \multirow{2}{*}{$\begin{array}{c}\text { Capital } \\
\text { income } \\
\text { taxes }\end{array}$} & & & & & & fare & & \\
\hline Age & Year & & & & & & age & taxes & OASDJ & $\mathrm{HI}$ & AFDC & General & $\mathrm{UI}$ & Stamps \\
\hline 90 & 1989 & -7434.0 & 0.0 & 0.0 & 1007.9 & 445.7 & -1.3 & 729.7 & 4744.5 & 4226.3 & 0.0 & 6149 & 0.0 & 30.3 \\
\hline
\end{tabular}




\section{APPENDIX TABLE 5}

Accounts for Age Zero and Future Male Generations under Altemative Policy Changes $(r=.06, g=.0075)$ (thousands of dollars)

\begin{tabular}{|c|c|c|c|c|c|c|c|c|c|}
\hline \multirow{2}{*}{$\begin{array}{l}\text { Generation's } \\
\text { age in } 1989\end{array}$} & \multirow{2}{*}{$\begin{array}{l}\text { Current } \\
\text { policy }\end{array}$} & \multirow{2}{*}{$\begin{array}{c}\text { Capital gains } \\
\text { tax ctit }\end{array}$} & \multirow{2}{*}{$\begin{array}{l}\text { No } \\
\text { reduction } \\
\text { in Social } \\
\text { Security }\end{array}$} & \multirow{2}{*}{$\begin{array}{l}\text { Faster } \\
\text { Medicare } \\
\text { growth }\end{array}$} & \multirow{2}{*}{$\begin{array}{l}\$ 500 \text { billion } \\
\text { S\&L bailout }\end{array}$} & \multirow{2}{*}{$\begin{array}{c}\text { Slower } \\
\text { growth in } \\
\text { govermment } \\
\text { consumption }\end{array}$} & \multicolumn{3}{|c|}{$\begin{array}{c}\text { Current budget } \\
\text { agreement }\end{array}$} \\
\hline & & & & & & & $\mathrm{A}$ & B & $C$ \\
\hline 0 & 73.7 & 73.6 & 73.3 & 73.2 & 73.7 & 73.7 & 75.8 & 75.8 & 73.8 \\
\hline 5 & 93.2 & 93.0 & 92.7 & 92.5 & 93.2 & 93.2 & 95.7 & 95.7 & 93.3 \\
\hline 10 & 116.8 & 116.6 & 116.2 & 115.9 & 116.8 & 116.8 & 119.9 & 119.9 & 117.0 \\
\hline 15 & 145.3 & 145.0 & 144.5 & 144.1 & 145.3 & 145.3 & 148.9 & 148.9 & 145.6 \\
\hline 20 & 169.1 & 168.7 & 168.1 & 167.7 & 169.1 & 169.1 & 173.0 & 173.0 & 169.7 \\
\hline 25 & 193.0 & 192.6 & 191.7 & 191.2 & 193.0 & 193.0 & 197.4 & 197.4 & 193.8 \\
\hline 30 & 194.5 & 194.0 & 192.9 & 192.3 & 194.5 & 194.5 & 198.9 & 198.9 & 195.4 \\
\hline 35 & 186.0 & 185.5 & 184.1 & 183.3 & 186.0 & 186.0 & 190.3 & 190.3 & 186.9 \\
\hline 40 & 176.2 & 175.6 & 173.6 & 172.6 & 176.2 & 176.2 & 180.5 & 180.5 & 177.1 \\
\hline 45 & 155.4 & 154.8 & 153.1 & 150.6 & 155.4 & 155.6 & 159.8 & 159.8 & 156.4 \\
\hline 50 & 114.1 & 113.6 & 112.7 & 108.7 & 114.1 & 114.1 & 118.3 & 118.3 & 115.1 \\
\hline 55 & 69.7 & 69.3 & 69.7 & 63.8 & 69.7 & 69.7 & 73.9 & 73.9 & 70.7 \\
\hline 60 & 18.9 & 18.6 & 18.9 & 13.0 & 18.9 & 18.9 & 23.1 & 23.1 & 20.2 \\
\hline 65 & -31.8 & -32.1 & -31.8 & -36.9 & -31.8 & -31.8 & -28.3 & -28.3 & -30.5 \\
\hline 70 & -42.7 & -42.9 & -42.7 & -46.5 & -42.7 & -42.7 & -40.1 & -40.1 & -41.6 \\
\hline 75 & -41.5 & -41.6 & -41.5 & -44.1 & -41.5 & -41.5 & -39.7 & -39.7 & -40.6 \\
\hline 80 & $-35,6$ & -35.7 & -35.6 & -37.2 & -35.6 & -35.6 & -34.4 & -34.4 & -349 \\
\hline 85 & -28.2 & -28.3 & -28.2 & -29.0 & -28.2 & -28.2 & -27.4 & -27.4 & -27.4 \\
\hline 90 & -1.5 & -1.5 & -1.5 & -1.5 & -1.5 & -1.5 & -1.5 & -1.5 & -1.5 \\
\hline $\begin{array}{l}\text { Future } \\
\text { generations }\end{array}$ & 89.5 & 90.8 & 94.5 & 105.3 & 98.9 & 64.8 & 49.8 & 70.2 & 83.1 \\
\hline
\end{tabular}

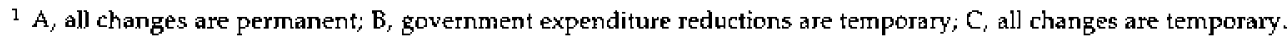




\section{APPENDIX TABLE 5a}

Accounts for Age Zero and Future Male Generations under Alternative Policy Simulations $(r=.03, g=.0075)$ (thousands of dollars)

\begin{tabular}{|c|c|c|c|c|c|c|c|c|c|}
\hline \multirow{2}{*}{$\begin{array}{l}\text { Generation's } \\
\text { age in } 1989\end{array}$} & \multirow{2}{*}{$\begin{array}{l}\text { Current } \\
\text { policy }\end{array}$} & \multirow{2}{*}{$\begin{array}{c}\text { Capital gains } \\
\text { tax cut }\end{array}$} & \multirow{2}{*}{$\begin{array}{l}\text { No } \\
\text { reduction } \\
\text { in Social } \\
\text { Security }\end{array}$} & \multirow{2}{*}{$\begin{array}{l}\text { Faster } \\
\text { Medicare } \\
\text { growth }\end{array}$} & \multirow{2}{*}{$\begin{array}{l}\$ 500 \text { billion } \\
\text { S\&L bailout }\end{array}$} & \multirow{2}{*}{$\begin{array}{c}\text { Slower } \\
\text { growth in } \\
\text { government } \\
\text { consumption }\end{array}$} & \multicolumn{3}{|c|}{$\begin{array}{c}\text { Current budget } \\
\text { agreement }\end{array}$} \\
\hline & & & & & & & A & $\mathrm{B}$ & C \\
\hline 0 & 203.8 & 203.3 & 200.6 & 199.1 & 203.8 & 203.8 & 210.3 & 210.3 & 203.9 \\
\hline 5 & 225.3 & 224.7 & 221.7 & 220.0 & 225.3 & 225.3 & 232.3 & 232,3 & 225.4 \\
\hline 10 & 247.7 & 247.1 & 243.8 & 241.9 & 247.7 & 247.7 & 255.3 & 255.3 & 247.9 \\
\hline 15 & 270.7 & 270.0 & 266.4 & 264.3 & 270.7 & 270.7 & 278.9 & 278.9 & 271.1 \\
\hline 20 & 280.1 & 279.3 & 275.5 & 273.3 & 280.1 & 280.1 & 288.3 & 288.3 & 280.8 \\
\hline 25 & 292.0 & 291.1 & 286.9 & 284.4 & 292.0 & 292.0 & 300.5 & 300.5 & 292.9 \\
\hline 30 & 272.5 & 271.6 & 267.0 & 264.5 & 272.5 & 272.5 & 280.5 & 280.5 & 273.5 \\
\hline 35 & 243.2 & 242.3 & 237.4 & 234.7 & 243.2 & 243.2 & 250.8 & 250.8 & 244.3 \\
\hline 40 & 215.7 & 214.7 & 209.1 & 206.0 & 215.7 & 215.7 & 222.9 & 222.9 & 216.8 \\
\hline 45 & 176.2 & 175.3 & 171.1 & 165.1 & 176.2 & 176.2 & 183.4 & 183.4 & 177.4 \\
\hline 50 & 117.3 & 116.6 & 114.6 & 106.2 & 117.3 & 117.3 & 123.9 & 123.9 & 118.4 \\
\hline 55 & 60.5 & 59.8 & 60.5 & 49.7 & 60.5 & 60.5 & 66.7 & 66.7 & 61.5 \\
\hline 60 & 3.4 & 2.9 & 3.4 & -6.4 & 3.4 & 3.4 & 9.2 & 9.2 & 4.8 \\
\hline 65 & -47.1 & -47.5 & -47.1 & -54.9 & -47.1 & -47.1 & -42.5 & -42.5 & -45.6 \\
\hline 70 & -54.3 & -54.6 & -54.3 & -59.8 & -54.3 & -54.3 & -51.0 & -51.0 & -53.1 \\
\hline 75 & -49.6 & -49.8 & -49.6 & -53.1 & -49.6 & -49.6 & -47.3 & -47.3 & -48.6 \\
\hline 80 & -40.6 & -40.7 & -40.6 & -42.6 & -40.6 & -40.6 & -39.1 & -39.1 & -39.8 \\
\hline 85 & -30.8 & -30.8 & -30.8 & -31.6 & -30.8 & -30.8 & -29.9 & -29.9 & -29.9 \\
\hline 90 & -1.5 & -1.5 & -1.5 & -1.5 & -1.5 & -1.5 & -1.5 & -1.5 & -1.5 \\
\hline $\begin{array}{l}\text { Future } \\
\text { generations }\end{array}$ & 249.7 & 250.8 & 259.0 & 272.9 & 253.9 & 217.9 & 203.6 & 233.2 & 246.5 \\
\hline
\end{tabular}

A all changes are permanent; $B$, government expenditure xeductions are temporary; $C$, all changes are temporary 
APPENDIX TABLE 6

Accounts for Age Zero and Future Female Generations under Alternative Policy Changes $(r=.06, g=.0075)$ (thousands of dollars)

\begin{tabular}{|c|c|c|c|c|c|c|c|c|c|}
\hline \multirow{2}{*}{$\begin{array}{l}\text { Generation's } \\
\text { age in } 1989\end{array}$} & \multirow{2}{*}{$\begin{array}{l}\text { Current } \\
\text { policy }\end{array}$} & \multirow{2}{*}{$\begin{array}{l}\text { Capital } \\
\text { gains } \\
\text { tax cut }\end{array}$} & \multirow{2}{*}{$\begin{array}{l}\text { No } \\
\text { reduction } \\
\text { in Social } \\
\text { Security }\end{array}$} & \multirow{2}{*}{$\begin{array}{l}\text { Faster } \\
\text { Medicare } \\
\text { growth }\end{array}$} & \multirow{2}{*}{$\begin{array}{l}\$ 500 \text { billion } \\
\text { S\&L bajlout }\end{array}$} & \multirow{2}{*}{$\begin{array}{c}\text { Slower } \\
\text { growth in } \\
\text { government } \\
\text { consumption }\end{array}$} & \multicolumn{3}{|c|}{$\begin{array}{c}\text { Current budget } \\
\text { agrement }\end{array}$} \\
\hline & & & & & & & A & B & $\mathrm{C}$ \\
\hline 0 & 36.4 & 36.4 & 36.1 & 35.7 & 36.4 & 36.4 & 38.1 & 38.1 & 36.5 \\
\hline 5 & 46.5 & 46.4 & 46.0 & 45.6 & 46.5 & 46.5 & 48.4 & 48.4 & 46.6 \\
\hline 10 & 60.4 & 60.3 & 59.8 & 59.2 & 60.4 & 60.4 & 62.8 & 62.8 & 60.6 \\
\hline 15 & 70.7 & 70.6 & 70.0 & 69.3 & 70.7 & 70.7 & 73.3 & 73.3 & 71.0 \\
\hline 20 & 85.5 & 85.3 & 84.5 & 83.6 & 85.5 & 85.5 & 88.5 & 88.5 & 85.9 \\
\hline 25 & 91.0 & 90.8 & 89.8 & 88.7 & 91.0 & 91.0 & 94.2 & 94.2 & 91.6 \\
\hline 30 & 90.9 & 90.7 & 89.4 & 87.9 & 90.9 & 90.9 & 94.1 & 94.1 & 91.5 \\
\hline 35 & 86.9 & 86.7 & 85.1 & 83.2 & 86.9 & 86.9 & 90.2 & 90.2 & 87.6 \\
\hline 40 & 78.2 & 77.9 & 75.8 & 73.5 & 78.2 & 78.2 & 81.4 & 81.4 & 78.9 \\
\hline 45 & 62.9 & 62.6 & 60.9 & 56.9 & 62.9 & 62.9 & 66.2 & 66.2 & 63.6 \\
\hline 50 & 41.0 & 40.7 & 39.7 & 33.7 & 41.0 & 41.0 & 44.3 & 44.3 & 41.6 \\
\hline 55 & 11.7 & 11.5 & 11.7 & 3.5 & 11.7 & 11.7 & 15.2 & 15.2 & 12.3 \\
\hline 60 & -22.5 & -22.7 & -22.5 & -30.8 & -22.5 & -22.5 & -19.0 & -19.0 & -21.6 \\
\hline 65 & -53.7 & -53.8 & -53.7 & -61.0 & -53.7 & -53.7 & -50.5 & -50.5 & -52.7 \\
\hline 70 & -60.2 & -60.3 & -60.2 & -66.0 & -60.2 & -60.2 & -57.6 & -57.6 & -59.3 \\
\hline 75 & -57.9 & -58.0 & -57.9 & -61.9 & -57.9 & -57.9 & -56.0 & -56.0 & -57.1 \\
\hline 80 & -50.8 & -50.8 & -50.8 & -53.2 & -50.8 & -50.8 & -49.5 & -49.5 & -50.2 \\
\hline 85 & -42.7 & -42.7 & -42.7 & -43.7 & -42.7 & -42.7 & -41.8 & -41.8 & -41.8 \\
\hline 90 & -7.4 & -7.4 & -7.4 & -7.4 & -7.4 & -7.4 & -7.4 & -7.4 & -7.4 \\
\hline $\begin{array}{l}\text { Future } \\
\text { generations }\end{array}$ & 44.2 & 44.9 & 46.5 & 51.4 & 48.9 & 32,0 & 25.0 & 35.2 & 41.1 \\
\hline
\end{tabular}

${ }_{1} \mathrm{~A}$, all changes are permanent; $\mathrm{B}$, government expenditure reductions ale temporary; $\mathrm{C}$, all changes are temporary. 
APPENDIX TABLE 6a

Accounts for Age Zero and Future Female Generations under Altemative Policy Simulations ( $r=.03$,

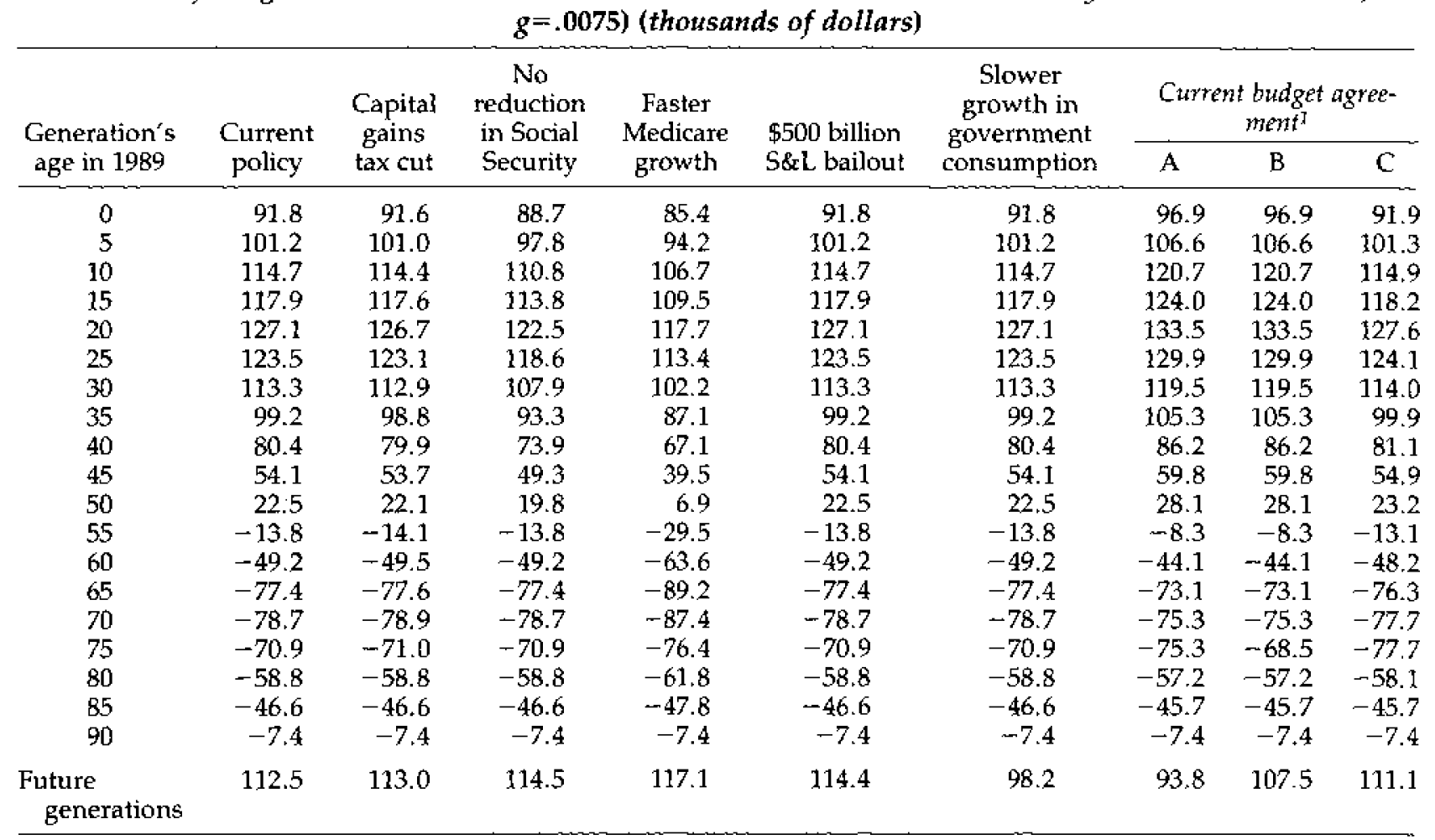

${ }_{1}$ A all changes are permanent; $B$, govemment expenditute reductions ate temporary; $C_{r}$ all changes are temporary. 